\title{
Lifespan Development of Syntactic Ability from Early Childhood to Old Age
}

\author{
Ji Hye Yoon ${ }^{\mathrm{a}}$, Hye Yeong Jeong ${ }^{\mathrm{b}}$, YoonKyoung Lee ${ }^{\mathrm{a}}$, Yu-Seop Kim, Jieun Choi ${ }^{\mathrm{d}}$, Jisu Kim ${ }^{\mathrm{c}}$ \\ ${ }^{a}$ Division of Speech Pathology and Audiology, Hallym University, Chuncheon, Korea \\ ${ }^{b}$ Department of Speech Pathology, Graduate School of Health Sciences, Hallym University, Chuncheon, Korea \\ 'School of Software, Hallym University, Chuncheon, Korea \\ ${ }^{d}$ Department of Speech-Language Pathology and Audiology, Graduate School of Hallym University, Chuncheon, Korea
}

Correspondence: Ji Hye Yoon, $\mathrm{PhD}$

Division of Speech Pathology and Audiology, Hallym University, 1 Hallimdaehak-gil, Chuncheon 24252, Korea

Tel: $+82-33-248-2224$

Fax: +82-33-256-3420

E-mail: j.yoon@hallym.ac.kr

Received: October 5, 2018

Revised: November 8, 2018

Accepted: November 8, 2018

This work was supported by the Hallym Leading Research Group Support Program of 2017 (No. HRF-LGR-2017-0002)

We thank Song Yi Han, Jun Sang Min, Yewon Yang, Seung A Oh, Jin Ju Choi, \& Weon Kyeong Hong for their assistance in collecting and analyzing the data.

\begin{abstract}
Objectives: The purpose of this study is to examine the developmental tendency of syntactic development from early childhood to old age. Methods: Normal developing children, adolescents, young adults, middle adults, and the elderly $(N=120)$ participated in the study. Fifty language utterances from each participant were taken from a semi-structured conversation. In terms of the characteristics on syntactic output, the number of syllables, postposition, suffixes, and functors per utterances were measured. In terms of the characteristics on syntactic length, mean length of utterance in morphemes (MLU-m), mean length of utterance in words (MLU-w), mean length of utterance in clutters (MLU-c), and mean syntactic length (MSL) were measured. In terms of the characteristics on syntactic type, the percent of simple sentence and complex sentence were measured. Results: Most of parameters increased from early childhood to adolescence significantly, then decreased in the age groups after young adults, and slightly increased in middle adults, and decreased in the elderly. Discriminant analysis showed the number of suffixes per utterance, the number of functors per utterance, MLU-m, and MSL were good discriminators between the age groups. Conclusion: The findings present syntax indicators that distinguish each age group in order to confirm the development of syntactic ability from the viewpoint of the whole life span.
\end{abstract}

Keywords: Lifelong language development, Syntactic development, Sentence, Morpheme
언어는 생각을 표현하는 상징적 기호로 부호화되어 의사소통을 가능케 하는 수단이 되며, 일반적으로 '의미, 구문, 화용'의 세 가지 영역으로 구분된다(Bloom \& Lahey, 1978; Kim, 2014; Lahey, 1988). 의미 영역은 단어의 개념이나 의미적 관계에 대한 표현 및 이해 등 을 의미하고, 구문 영역은 형태소 및 낱말의 나열 등의 규칙을 통해 구, 절, 문장 등을 조직하며, 화용 영역은 사회적 상황에 따른 말의 유연성과 담화 기술 등을 처리한다(Kim, 2014; Lee, Park, Park, \& Kim, 2003; Paul \& Norbury, 2012). 이 영역들은 독립적으로 존립 하지 않고 인지언어활동 내에서 상호작용하며 발달하게 된다. 고도 의 복잡한 과정으로 이루어진 언어는 지각, 이해, 운동 능력 등을 필요로 하며, 각 언어 영역의 습득과 발달 과정은 인간의 뇌가 신경
생리학적으로 발달하는 것과 무관하지 않다. 뇌의 전 영역 중 측두 엽은 주로 언어의 '의미 영역'을 담당하여 내용어를 처리하고 어휘 를 저장하여 의미습득에 주요한 역할을 처리한다(Shin \& Kim, 2005). 또한 전전두엽(prefrontal cortex)은 계획, 조직, 개시 등의 기 능을 담당하는데 특히 하전두이랑(inferior frontal gyrus)은 문법 형태소 처리나 단어를 연결시켜 문장을 만드는 등의 고차원적인 언 어(high-order processes)를 처리한다(Damasio \& Anderson, 1993; Duffy \& Campbell, 1994; Filley, 1995; Yeom, 2006). 이러한 이유에 서 전두엽은 단어 및 문장 산출을 위해 목표 발화를 생성하고 문법 구조 등을 고려하여 문장을 구성하는 '구문 영역'과 관련이 있다. ‘화용 영역' 또한 전전두엽과 관련이 있을 수 있는데, 상황이나 맥락 
에 따른 판단과 사회적 규범과 충동 및 억제 능력에 영향을 주어 (Cummings, 1993; Duffy \& Campbell, 1994; Kim, 2001; Mega \& Cummings, 1994) 의사소통 수단으로서 언어를 적절히 활용할 수 있게 한다.

인간의 뇌기능은 발전하기도 하지만 장노년기가 되면서 신경생 리학적 변화로 인하여 그 기능이 쇠퇴할 수도 있다. 인간의 뇌를 구 성하는 신경세포의 개수는 1,050 억 개까지(Andersen, Korbo, \& Pakkenberg, 1992) 증가하다가 감소하게 되므로 인간의 뇌발달 곡 선은 출생 이후 성인기에 이르기까지 포물선의 형태를 그린다. 특히 회백질은 아동기부터 성장하다가 청소년기에 신경연접의 가지치기 와 수초화로 인해 백질과 더불어 증가하여 12-14세경에 최대치를 기록 후 노화에 따른 퇴행 등으로 회백질의 부피가 감소하는 양상 을 보인다(Park \& Kim, 2011; Park \& Kim, 2015). 영역별로는 전두 엽과 일차감각운동피질 영역부터 시작되어 두정엽, 후두엽 순으로 회백질의 용적과 두께 감소가 점차 진행된다(Part \& Kim, 2011). 따 라서 성장뿐만 아니라 감소 및 쇠퇴되는 양상까지도 발달적 변화로 간주하는 '전생애 발달(lifespan development)'의 개념(Baltes, 1987) 은 뇌기능의 변화를 이해하는 데 유용하다. 그뿐만 아니라 전생애 발달 측면은 최근 노인 인구 증가로 대두되고 있는 고령화와 관련 된 신체적, 인지적, 사회적 변화와 맞물려 더욱 중요하게 인식되고 있다. 인구통계학적으로 65 세 이상의 노인 인구가 $7 \%$ 이상 $14 \%$ 미 만이면 고령화 사회(ageing society), $14 \%$ 이상 20\% 미만이면 고령 사회(aged society), $20 \%$ 이상이면 초고령 사회(super-aged society) 라 하는데 우리나라의 경우, 2017년에 이미 65세 이상의 인구가 전 체 인구의 $13.8 \%$ 를 넘어 고령화 사회에 진입하게 되었으며 2050년 에는 노인의 인구가 1,000 만 명이 넘어 인구 5 명 중 1 명 $(20 \%)$ 이 노인 일 것으로 전망되고 있다(Statistic Korea, 2017).

이렇듯 전생애 발달과 고령화에 대한 관심의 일환으로 다양한 연령대를 대상으로 각 언어 요소들에 대한 특성을 확인하는 연구 가 시도되고 있으나 대부분의 선행연구는 아동기와 청소년기를 비 교하거나 성인기와 노년기를 비교하는 방식으로 이루어졌기 때문 에 언어 발달의 전 과정을 살펴보는 것에는 제한이 있어 왔다. 이에 Lee 등(2017)은 영유아기부터 노년기까지의 전 연령대를 대상으로 생애 전반에 걸쳐 꾸준하게 발달하는 언어 영역인 어휘의미발달 (Nippold, 2007)을 확인하기 위해 품사별 전체 어휘수(total number of word, TNW), 다른 어휘수(number of different word, NDW), 어휘다양도(type-token ratio, TTR) 등을 분석하였으며, 판별분석 결과 부사 $\mathrm{TNW}$, 동사 $\mathrm{NDW}$, 형용사 $\mathrm{TNW}$, 감탄사 $\mathrm{NDW}$ 가 각 연 령 집단을 가장 잘 판별해주는 요인임을 확인하였다. 의미가 발달 해감에 따라 화자가 의도한 의미를 원활히 전달하기 위한 형식을
갖추게 되면서 구문 능력 또한 발달하게 된다(Lee et al., 2003; Paul \& Norbury, 2012). 즉, 단어조합의 배열규칙을 이해하고 기본 문법 단위(어절, 구, 절)를 토대로 조사와 어미와 같은 문법형태소를 포함 한 문장을 산출하게 되는 것이다(Yi, 2015). 이렇게 발화를 생성하 기 위해서는 앞서 언급되었던 전두엽의 집행기능과 작업기억, 즉 발 화를 조직하고 계획하며 동시에 산출된 자신의 발화 정보를 유지 시키며 모니터링할 수 있는 능력이 필수적이다. 특히 인간의 뇌엽 중 발달과 감퇴의 변화가 큰 전두엽 기능과 구문 능력이 관련이 있 고(Park \& Kim, 2015), 노화로 인한 작업기억 능력의 감소가 복문 사용비율을 감소시키거나 내포문과 주절로 이루어지는 문장의 구 성에 영향을 미친다는 측면(Gibson, 1998)에서 구문 특성은 뇌의 발달을 반영하는 또 하나의 주요한 지표가 될 수 있다.

구문 발달에 대한 전통적인 관점은 다음과 같이 보고되었다. 영 유아기에는 성인의 소리와 유사한 소리들을 사용하며 옹알이를 보 이다가 점차 의미 있는 첫 낱말을 산출하게 되며 주로 한 낱말로 표 현한다. 2-4세 정도가 되면 아동들은 대략 1.87-5.17의 평균형태소 를 보였고(Miller \& Chapman, 1981) 아이들은 성장하면서 관형절, 부사절, 명사절의 종속절을 더 빈번하게 사용하게 되며, 후기 청소 년까지 communication-unit (C-unit)의 평균길이와 절의 수는 계 속 증가된다(Loban, 1976; as cited in Nippold, Hesketh, Duthie, \& Mansfield, 2005). 아동기를 지나 12세부터 성인기 초기 나이의 중 고등학교에 다니는 청소년기를 고급언어시기(advanced language) 라고 하는데 고급언어시기에 있는 청소년들은 언어 발달의 기본적 인 기술들을 모두 습득했을 뿐만 아니라, 복합문을 이해하고 표현 할 수 있고(Paul \& Norbury, 2012) 문장 내, 문장 간의 새로운 구문 기술들을 사용하며, 파생형태소에 대한 이해력이 증가한다. 또한 청소년기에는 형태구문적 표지(동사표지, 부정형 등)를 빈번히 사 용하며(Reed, Griffith, \& Rasmussen, 1998) 접속사와 기타 응집장 치를 보다 효과적으로 사용하고(Nippold, 2007) 성인의 구문 구조 와 유사한 구조 형태를 사용한다(Scott \& Stokes, 1995). 성인기 이 후에는 연령이 증가됨에 따라 발화 내용을 반복하고 내용어 수가 감소되며 긴 심이 증가한다(Ardila \& Rosselli, 1996; Mackenzie, 2000; Shewan \& Henderson, 1988). 또한 연령이 증가할수록 구문 구조, 문장 분절(segmentation), 삽입어 등의 구문 복잡성이 감소하 였고, 특히 70대 중반에서 가장 빠른 속도로 구문 능력이 저하된다 고보고되었다(Kemper, Thompson, \& Marquis, 2001).

우리나라의 경우에도 다양한 연령대를 대상으로 구문 발달에 대한 연구가 이루어졌다. 먼저 학령전기 아동 연구는 한국 2-4세 아동을 대상으로 형태소, 낱말, 어절에 대한 평균발화길이와 최장 발화길이, 최단발화길이를 살펴보았는데 평균형태소길이와 최장 
발화길이는 연령이 증가할수록 집단 간 유의미한 차이를 보였으며 (Kim, 1997) 학령전 아동의 문법형태소 습득, 구문표현력 발달에 대한 종단연구 및 아동의 구문 발달에 따른 용언 발달 등의 연구도 이루어졌다(Pae, 1997; Lee, 2010; Lee et al., 2003). 학령기에는 단순 언어장애 아동을 대상으로 담화 유형에 따른 구문복잡성(C-unit 당 평균낱말길이, 평균 절의 수)과 종속절의 유형 사용률을 확인하 였으며 대화보다 설명담화에서 관형절과 부사절 사용률이 더 많이 사용됨을 관찰하였다(Lee, Kim, \& Yun, 2008). 또한 구문 능력을 양적으로 측정하는 분석 기준인 최소종결단위(Terminable unit, T-unit)를 사용하여 구문을 분석하기도 하였는데 10-12세에서는 최소종결단위 길이가 늘어나고, 12-14세에서는 안긴절 사용이 증 가하였으며, 서술담화보다 설명담화와 쓰기에서 구문 발달이 연령 별로 뚜렷하게 나타났다(Yim, Park, Kim, \& Seo, 2008). 설명과 경 험이야기를 통한 학령기 및 청소년의 구문 발달 특성 연구의 경우 에도 T-unit수, 전체 낱말수와 T-unit 길이, 절의 밀도가 학년이 올 라감에 따라 증가하였다(Kim \& Kim, 2011). 성인기로 접어들면서 는 단순히 MLU를 분석하기보다는 담화 수준에서 문맥상 명료하 고 주제에 적합한 정확한 정보를 제공하는 단어로 정의되는 correct information unit (CIU)을 사용하여 발화를 분석하거나(Choi, 2012; Choi, 2014; Jeon \& Kim, 2015; Kwon, Kim, Choi, Na, \& Lee, 1998; Lee, Park, \& Son, 2011) 문법형태소 측면에 초점을 두어 분석 하기도 하고(Kim \& Kim, 2009), 문해 능력과 자발화의 구문적 특 성을 살펴보거나 퇴행성 질환군과의 비교를 통한 노년층의 발화 특성을 제시하였다(Ha, Jung, \& Sim, 2009; Kim \& Kim, 2009; Lee \& Kim, 2005).

현재까지 이루어진 구문 관련 연구를 종합해 보면, 연구대상자 측면에서 특정 연령대에 국한되어 영유아 시기부터 노년기까지 이 르는 전생애적 발달 변화 양상을 살펴보지 않았다. 연구과제 측면 에서는 학령전기의 경우 주로 자유놀이 상황을 통한 자발화를 사 용하였고, 학령기 및 청소년의 경우 대화 또는 설명담화, 서술담화 등의 과제를 사용하였으며, 성인 및 노인의 경우, 대화를 통한 자발 화 수집 또는 그림 설명하기, 이야기 말하기 등의 다양한 과제를 사 용하였기 때문에(Jeon \& Kim, 2015; Kim, 1997; Lee \& Kim, 2001; Lee \& Kim, 2012; Lee et al., 2003; Lee et al., 2008; Lee et al., 2011; Yim et al., 2008) 발달의 연속선상에서 집단을 비교하는 데 제약이 있었다. 자료분석 측면에서는 연구에 따라 평균발화길이를 측정하 거나 문장의 유형이나 성분절을 분석하는 등 다양한 분석지표가 사용되어 구문 발달의 특성을 하나의 관점에서 해석하기 어려운 제한점을 가진다(Kim \& Kim, 2011; Lee et al., 2008; Lee et al., 2003). 이에 본 연구에서는 초기아동기(유아기)에서 노년기에 이르기까
지의 구문 발달 특성을 살펴보기 위해 구문의 산출, 길이, 유형을 아우르는 지표(발화당 음절수, 발화당 조사수, 발화당 어미수, 발 화당 기능어수, 평균형태소길이, 평균낱말길이, 평균어절길이, 평균 구문길이, 전체문장수, 단문 비율, 복문 비율)를 사용하여 통일된 대화절차를 통해 수집된 50 개 발화를 분석하였다. 그리고 여러 측 정치 중 각 집단 연령을 가장 잘 판별해 준 측정치를 확인하여 각 연 령대를 대표하는 전생애적 구문 발달의 지표를 제시하고자 하였다.

\section{연구방법}

\section{연구대상}

자료수집 시, 표본수의 산출은 연구설계 단계에서 $\mathrm{G}^{*}$ Power를 통한 검정 결과(large effect size $=.40$; power $=.9$; 전체 표본수 $=114$ )에 근접한 120 명을 대상으로 하였으며, 본 연구의 대상자들 은 공동저자의 선행연구(Lee et al., 2017)에 참여하였던 대상자와 동일하였다. 연구대상자는 Havighurst (1973)의 발달 시기 분류에 근거하여 생애 발달을 총 6시기(초기아동기, 후기아동기, 청소년기, 초기성인기, 후기성인기, 노년기)로 나누었으며 각 시기별로 20 명이 포함되었다. 각 시기의 연령 범위는 초기아동기는 3-6세, 후기아동 기는 7-12세, 청소년기는 13-18세, 초기성인기는 19-35세(교육년수 $14.60 \pm 1.95$ ), 후기성인기는 36-60세(교육년수 $14.45 \pm 2.25$ ), 노년 기는 61 세 이상(교육년수 $11.80 \pm 2.98$ )이었다. 정상 발달 과정의 대 상자를 선정하기 위하여 다음과 같은 기준을 적용하였다. 초기아 동기부터 청소년기까지는 교사나 주양육자에 의해 운동, 감각, 신 체, 정서 등에서 문제 및 특이사항이 없으며, 수용·표현어휘력검사 (Receptive \& Expressive Vocabulary Test, REVT; Kim, Hong, Kim, Jang, \& Lee, 2009)에서 언어 능력이 정상 범위에 속하는 경우만 포 함하였다. REVT 규준이 없는 청소년기 대상자들은 한국판 웩슬 러 성인지능검사 4판(Korean-Wechsler Adult Intelligence Scale IV, K-WAIS-4; Hwang, Kim, Park, Choi, \& Hong, 2012)의 하위 검 사 중 ‘어휘'와 ‘이해’ 영역 환산점수 평균인 10점부터 -1 표준편차 이상인 경우만 포함하였다. 초기성인기, 후기성인기 및 노년기는 건 강선별설문지(Christensen, Multhaup, Nordstrom, \& Voss, 1991) 와 한국판 간이정신상태검사(Korean-Mini Mental State Examination, K-MMSE; Kang, 2006)를 통해 정신적, 신경학적 질환의 병 력이 없고 정상 범위의 인지 기능을 가진 대상자만을 포함하였다. 연구대상자 정보는 Table 1 과 같다.

\section{자료수집 도구 및 절차}

발화 수집 과정에서 수집 도구나 절차에 영향받지 않기 위하여 
Table 1. Participants' characteristics

\begin{tabular}{lcccccc}
\hline & $E C(N=20)$ & $L C(N=20)$ & Adc $(N=20)$ & $Y A(N=20)$ & $L A(N=20)$ & $E d(N=20)$ \\
\hline Age (yr) & $5.55(.51)$ & $10.10(1.58)$ & $16.35(1.87)$ & $28.40(5.15)$ & $53.30(5.03)$ & $67.40(5.23)$ \\
Sex (male:female) & $11: 9$ & $7: 13$ & $7: 13$ & $13: 7$ & $5: 15$ & $10: 10$ \\
\hline
\end{tabular}

Values are presented as mean (SD).

$\mathrm{EC}=$ early childhood (preschooler); $\mathrm{LC}=$ late childhood (school aged child); $\mathrm{Adc}=$ adolescent; $\mathrm{YA}=$ young adult; $\mathrm{OA}=$ older adult; $\mathrm{Ed}=$ elderly.

모든 대상자들에게 한림 대화·화용평가프로토콜(Lee \& Choi, in press)의 동일한 절차를 통해 대화자료를 수집하였다. 대화의 세 가 지의 주제 중 두 가지의 주제는 4 장의 사진으로 연구대상자에게 제 공하고 나머지 한 가지의 주제는 사진 없이 검사자의 질문을 통해 검사를 진행하였다. 대화 시 사용될 사진은 가로 $110 \mathrm{~mm}$, 세로 85 $\mathrm{mm}$ 로 제공하였으며, 노인 대상자의 경우에는 가로 $200 \mathrm{~mm}$, 세로 $160 \mathrm{~mm}$ 크기로 사진을 확대하여 제공하였다.

대화주제는 다음과 같이 통제하였다. 아동 및 청소년에게는 '가 정생활, 학교(유치원)생활, 기타/친구'를 대화 주제로 제공하였고, 성인 및 노인에게는 '가정생활, 여가생활, 기타/친구'를 제공하였다. 모든 연령에게 공통된 주제는 '가정생활'과 '기타/친구'였으며, 연령 의 특성을 반영하여 아동 및 청소년에게는 ‘학교(유치원)생활'이, 성인 및 노인에게는 '여가생활'이 추가되었다. 각 대화 주제별로 세 가지의 소주제 질문이 제공되었다. 소주제는 '가정생활'에는 주말, 명절, 생일, '학교생활'에는 점심/쉬는시간, 방과후, 현장학습, '기타/ 친구'에는 놀이, 좋아하는 TV프로그램, '여가생활'에는 휴식시간, 취미활동, 모임활동으로 구성되었다.

대화 수집 절차로는 먼저 주제별로 준비된 각각의 사진을 한 봉 투에 담아 2 개의 봉투를 참가자에게 제시한 후 둘 중 하나를 선택 하게 하였다. 하나의 봉투를 참가자가 선택하면 봉투에 있는 사진 들을 꺼내 참가자에게 제공하고 살펴보게 한 뒤, 대화를 시작할 수 있는 기회를 제공하였다. 대상자가 자발적으로 대화를 개시하였을 때는 대화를 자연스럽게 이어나갔으나, 대상자가 대화를 개시하지 않으면 3초를 기다린 후 “가정생활은 어때(어떠세요)?” 또는 “여가 생활은 어때(어떠세요)?”라고 주제를 언급해 주었다. 언급해 주었 음에도 반응이 없는 경우에는, 소주제 질문을 하나씩 제공하였다. 준비한 소주제로 대화가 완료되는 경우에 대화를 종결하였다. 대 화 자료는 대화 상대자의 반응에 따라 달라질 수 있으므로 대화 상 대자로 참여하는 검사자의 영향을 최소화하도록 반응절차를 다음 과 같이 구조화하였다.

(1) 참가자가 자신의 대화차례에서 발화를 할 때, 대화차례를 받 지 않는 선에서 '응, 그래(네), 그렇구나(그렇군요)' 등의 중립적 인 반응으로 호응해준다.

(2) 참가자가 3 초 동안 아무 말을 하지 않거나, 끝맺는 말 또는 억
양을 사용하는 경우 대화차례가 끝났다고 간주하고, 검사자는 대상자의 발화를 반복하여 줌으로써 대화차례를 이어준다.

(3) 검사자의 대화차례 이후에 참가자가 발화를 이어나가지 않는 경우 3 초를 기다렸다가 “그리고(요)?" "또(요)?”와 같이 촉진 해준다.

(4) 참가자가 끝맺는 말, 할 말이 없다는 행동(시선, 미소, 무반응 등)을 보이면, 언급하지 않았던 소주제의 질문을 하거나 다음 화제를 선택하게 한다.

자료를 수집하는 검사자는 언어병리학전공 석사과정 5 명이었으 며, 자료를 수집하기 전 언어병리학 전공교수 1 인과 박사과정생 1 인 이 수집 절차에 대해 다음의 절차로 훈련을 진행하였다. 박사과정 생 1 인은 검사자 5 명(언어병리학전공 석사생)에게 수집 절차를 설 명해 준 뒤, 일주일 이내에 1-2명을 대상으로 예비연구를 시행하도 록 하였다. 박사과정생 1 인은 예비 연구를 통해 수집된 녹음 및 전 사된 자료를 다시 재검토한 뒤, 검사자가 정해진 절차를 충실하게 따랐다고 판단되는 경우에만 실제 자료수집을 진행하도록 하였다. 자료수집 및 검사 절차에 대해 완벽하게 숙지한 검사자는 대상자 모집을 통해 연락된 대상자, 관련 기관이나 보호자와 검사 일정을 조율하였다. 모든 대상자와 보호자는 연구목적, 내용 및 검사 절차 가 포함된 동의서에 동의한 후 자료가 수집되었다. 사후 분석을 위 하여 모든 대화내용은 MP3 (ICD-TX800)로 녹음되었다.

\section{자료 전사 및 분석}

대화자료를 수집한 검사자는 1 주일 이내에 녹음된 자료를 듣고 전사를 하였으며, 자료분석의 신뢰도를 위해 세 가지 주제에서 전 체 50 개의 발화를 추출하여 분석에 포함하였다. 50 발화의 선택 시 에는 대화 주제에 따른 영향력을 최소화하기 위하여 각 대화주제 의 비율을 $4: 4: 2$ 의 비율로 통일하였다. 구문 분석의 지표를 선정하기 위하여 한국 아동과 성인의 아동의 자발화 분석 연구(Kim, 1997; Kwon et al., 1998; Kim, Won, Lee, \& Yoon, 2017; Kim, Kim, Namkoong, Kim, \& Kim, 2006; Koo \& Choi, 2015; Kim, 2014; Lee \& $\mathrm{Kim}, 2001$; Lee \& Kim, 2005)를 검토하여 총 11가지 지표(전체문 장수, 발화당 음절수, 발화당 조사수, 발화당 어미수, 발화당 문법 기능어수, 평균형태소길이, 평균단어길이, 평균어절길이, 평균구문 
길이, 단문 비율, 복문 비율)를 선정하였다. 그 후, 아래와 같이 '구 문 산출, '구문 길이', '구문 유형'의 세 가지 측면으로 나누어 분류 하였다. '구문 산출'에는 '전체문장수, 발화당 음절수, 발화당 조사 수, 발화당 어미수, 발화당 문법기능어수’ 지표를 포함시켜 발화산 출량과 발화 내 단어의 사용 및 문법의 활용도를 살펴보고자 하였 다. '구문 길이'에는 ‘평균형태소길이, 평균낱말길이, 평균어절길이, 평균구문길이'를 포함시켰으며, '구문 유형'에는 '단문 비율, 복문 비율을 포함하였다. 이에 따른 자료 분석방법은 Appendix 1에 명 시하였다.

\section{통계 분석}

구문 발달 특성에 대해 살펴보기 위해 '구문 산출', '구문 길이', '구문 유형' 세 가지 측면으로 나누어 각 집단 간 일원배치분산분석 (one-way ANOVA)을 실시하였고, 11가지의 구문 측정치 중 각 연 령 집단의 특성을 가장 잘 판별할 수 있는 요인을 파악하기 위해 단 계선택방식의 판별분석(stepwise estimation-discriminate analysis)을 실시하여 상대적 기여도를 파악하였다.

\section{신뢰도}

자료 전사 및 분석 결과에 대한 신뢰도는 검사자와 언어병리학 을 전공하는 평가자(박사과정생 1 인) 간의 일치율로 측정하였다. 검사자와 평가자는 전사 및 분석 기준에 대하여 충분히 숙지한 상 태로 분석을 실시하였다. 먼저 전체 자료의 $10 \%$ 에 해당하는 12 명 을 무작위로 집단별 두 명씩 선정하여 각자 독립적으로 전사한 후 분석하도록 하였다. 전사 일치율은 $96 \%$ 였으며, 분석 일치율은 전체 문장수 $100 \%$, 발화당 음절수 $100 \%$, 발화당 조사수 $91.76 \%$, 발화 당 어미수 $93.27 \%$, 발화당 문법기능어수 $92.51 \%$, 평균형태소길이 $90.8 \%$, 평균낱말길이 $93.6 \%$, 평균어절길이 $95.7 \%$, 평균구문길이 $96.5 \%$, 단문 비율 $97.7 \%$, 복문비율 $94 \%$ 로 측정되었다.

\section{연구결과}

\section{집단 간 구문 산출 특성에 대한 분산분석 결과}

전체문장수는 초기아동기에서 청소년기까지 증가하다가 초기성 인기에 감소한 후 후기성인기에서 노년기까지는 비슷하게 유지되었 다. $\mathrm{ANOVA}$ 를 통해 연령 집단 간의 전체문장수 차이를 검증한 결 과 유의한 차이 $\left(F_{(5,114)}=9.241, p<.001\right)$ 를 보였다. Bonferroni 사후 분석 결과, 초기아동기는 후기아동기, 청소년기, 초기성인기, 후기 성인기보다 유의미하게 적은 문장수를 표현하였으며 청소년기는 초기아동기와 노년기 집단보다 유의미하게 많은 문장수를 표현한 것으로 나타났다.

발화당 음절수, 발화당 조사수, 발화당 어미수, 발화당 문법기능 어수는 모두 초기아동기에서 청소년기까지 증가하다가 초기성인기 에 감소한 후 후기성인기에서 다시 증가하였다가 노년기에는 감소하 였다. ANOVA를 통해 연령 집단 간의 차이를 검정한 결과 발화당 음절수 $\left(F_{(5,114)}=11.434, p<.001\right)$, 발화당 조사수 $\left(F_{(5,14)}=8.153, p<\right.$ $.001)$, 발화당 어미수 $\left(F_{(5,114)}=13.644, p<.001\right)$, 발화당 기능어수 $\left(F_{(5,114)}=\right.$ $12.357, p<.001)$ 모두에서 유의한차이를 보였다. Bonferroni 사후분 석 결과, 초기아동기는 산출 지표 모두에서 청소년기, 초기성인기, 후기성인기에 비해 유의미하게 적은 수를 보였다. 후기아동기는 발 화당 음절수와 발화당 조사수에서 청소년기에 비해 유의미하게 낮 은 수를 보였으며 발화당 어미수에서는 청소년기, 초기성인기, 후기 성인기에 비해 낮은 수를 보였고 문법기능어수에서는 청소년기, 후 기성인기에 비해 낮은 수를 보였다. 청소년기는 산출 지표 모두에서 초기아동기, 후기아동기, 노년기에 비해 유의미하게 많은 수를 보였 고 초기성인기는 산출 지표 모두에서 초기아동기에 비해 많은 수를 보였으며, 노년기는 발화당 음절수와 조사수, 기능어수에서 청소년 기, 후기성인기에 비해 유의미하게 적은수를 보였다. 구문 산출지표 에 따른 통계분석 결과는 Tables 2 와 3 , Figure 1 과 같다.

Table 2. Result of ANOVA in sentence output according to age group

\begin{tabular}{lccccccc}
\hline & EC & LC & Adc & YA & OA & Ed & $F$ \\
\hline TS & $37.2(4.3)$ & $42.1(6.0)$ & $46.5(2.0)$ & $43.4(3.2)$ & $43.1(5.6)$ & $39.2(6.3)$ & $9.241^{* * *}$ \\
SN & $13.8(3.9)$ & $17.8(7.4)$ & $27.1(7.6)$ & $20.9(3.8)$ & $23.1(6.9)$ & $16.8(6.9)$ & $11.434^{* * *}$ \\
PN & $1.5(.5)$ & $2.0(.9)$ & $2.8(.8)$ & $2.3(.4)$ & $2.7(.9)$ & $1.8(.9)$ & $8.153^{* * *}$ \\
EN & $2.1(.5)$ & $2.6(1.0)$ & $4.5(1.2)$ & $3.7(.6)$ & $4.0(1.2)$ & $3.1(1.5)$ & $13.644^{* * *}$ \\
FN & $3.6(1.0)$ & $4.7(1.7)$ & $7.3(1.9)$ & $6.0(1.0)$ & $6.8(2.1)$ & $4.9(2.3)$ & $12.357^{* * *}$ \\
\hline
\end{tabular}

Values are presented as mean (SD).

$\mathrm{EC}=$ early childhood (preschooler); $\mathrm{LC}=$ late childhood (school aged child); $\mathrm{Adc}=$ adolescent; $\mathrm{YA}=$ young adult; $\mathrm{OA}=$ older adult; $\mathrm{Ed}=$ elderly; $\mathrm{TS}=$ total number of sentences; $\mathrm{SN}=$ number of syllables per utterance; $\mathrm{PN}=$ number of a postpositional word per utterance; $\mathrm{EN}=$ number of a part added to the end of a word per utterance; $\mathrm{FN}=$ number of functional word per utterance.

${ }^{* * *} p<.001$. 
Table 3. Result of post-hoc analysis on sentence output

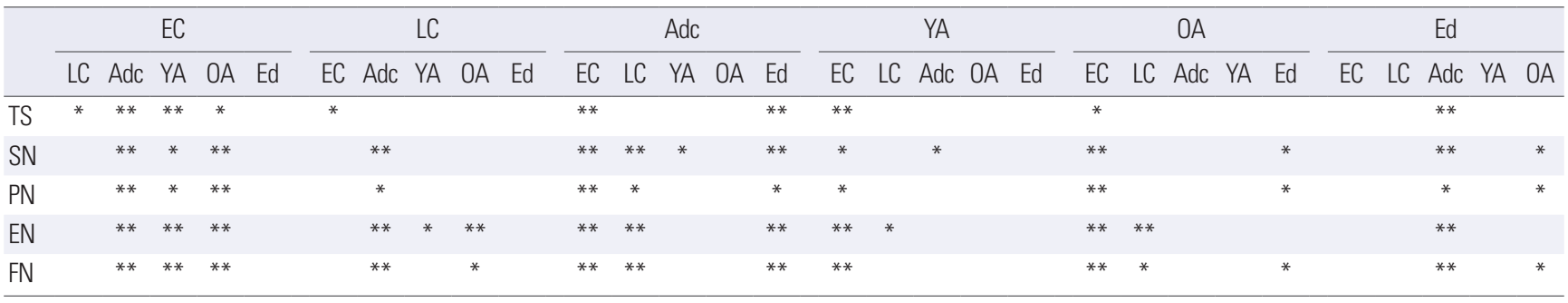

$E C=$ early childhood (preschooler); $L C=$ late childhood (school aged child); $\mathrm{Adc}=$ adolescent; $Y A=$ young adult; $\mathrm{OA}=$ older adult; $E d=$ elderly; TS=total number of sentences; $\mathrm{SN}=$ number of syllables per utterance; $\mathrm{PN}=$ number of a postpositional word per utterance; $\mathrm{EN}=$ number of a part added to the end of a word per utterance; $\mathrm{FN}=$ number of functional word per utterance. ${ }^{*} p<.05,{ }^{* *} p<.001$.
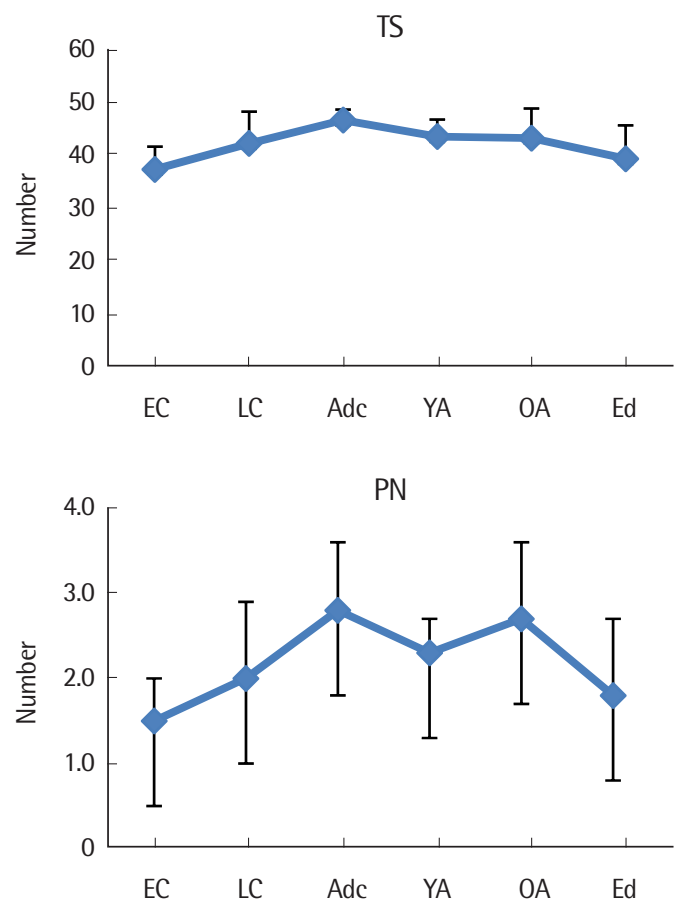

FN

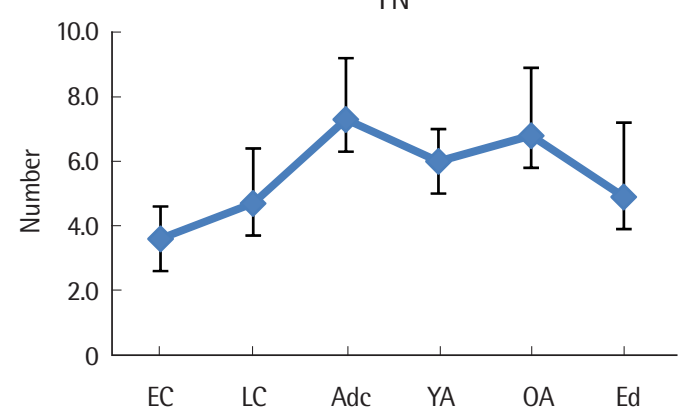

\section{집단 간 구문 길이 특성에 대한 분산분석 결과}

평균형태소길이, 평균낱말길이, 평균어절길이, 평균구문길이는 모두 아동기부터 청소년기까지 증가한 후 초기성인기에서 잠시 감 소하였다가 후기성인기에서 다시 증가하고 노년기에 다시 감소하였

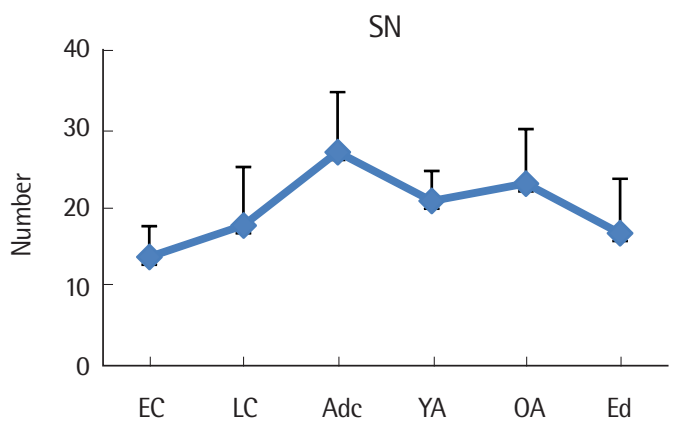

EN

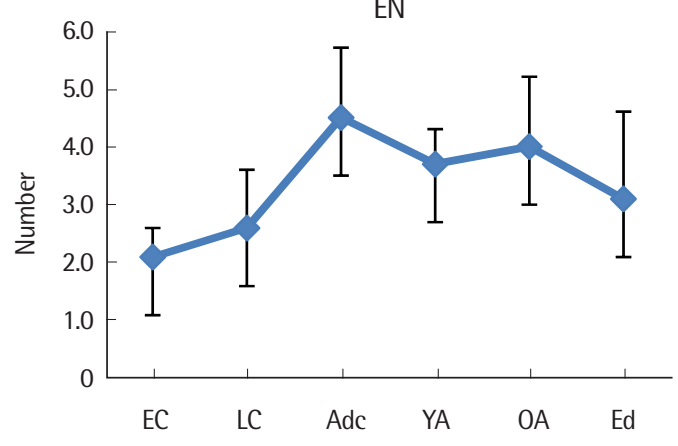

Figure 1. Analysis of sentence output ability according to age group.

$\mathrm{EC}=$ early childhood (preschooler); $\mathrm{LC}=$ late childhood (school aged child); $\mathrm{Adc}=$ adolescent; $\mathrm{YA}=$ young adult; $\mathrm{OA}=$ older adult; $\mathrm{Ed}=$ elderly; $\mathrm{TS}=$ total number of sentences; $\mathrm{SN}=$ number of syllables per utterance; $\mathrm{PN}=$ number of a postpositional word per utterance; $\mathrm{EN}=$ number of a part added to the end of a word per utterance; $\mathrm{FN}=$ number of functional word per utterance.

다. ANOVA를 통해 연령 집단 간의 차이를 검정한 결과 평균형태소 길이 $\left(F_{(5,114)}=11.830, p<.001\right)$, 평균낱말길이 $\left(F_{(5,114)}=10.265, p<.001\right)$, 평균어절길이 $\left(F_{(5,114)}=10.523, p<.001\right)$, 평균구문길이 $\left(F_{(5,14)}=10.004\right.$, $p<.001)$ 모두에서 유의미한 차이를 보였다. Bonferroni 사후분석 
결과, 평균형태소길이, 평균낱말길이, 평균어절길이, 평균구문길이 모두에서 아동기는 청소년기, 초기성인기, 후기성인기에 비해, 노년 기는 청소년기에 비해 유의하게 낮은 길이를 보였다. 또한 청소년기 는 초기아동기, 후기아동기, 노년기에 비해 평균형태소길이, 평균어 절길이, 평균길이에서 유의하게 높은 길이를 보였고, 초기성인기와 후기성인기는 아동기에 비해 평균낱말길이, 평균어절길이, 평균구 문길이 모두에서 유의하게 높은 길이를 보였다. 구문 길이 지표에 따른 통계분석 결과는 Tables 4 와 5 , Figure 2 와 같다.

\section{집단 간 구문 유형 특성에 대한 분산분석 결과}

단문 비율은 초기아동기부터 청소년기까지 감소되었다가 초기 성인기에 증가한 후 후기성인기에 다시 감소하였다가 노년기에 가 장 크게 증가하였다. $\mathrm{ANOVA}$ 를 통해 연령 집단 간의 차이를 검정 한 결과, 유의미하게 차이 $\left(F_{(5,114)}=8.970, p<.001\right)$ 를 보였다. Bonferroni 사후분석 결과, 초기아동기는 후기아동기와 청소년기에 비해 단문 사용률이 높았고, 후기아동기는 초기아동기와 노년기보다는 단문 사용률이 낮았다. 또한 청소년기는 초기아동기, 초기성인기,

Table 4. Result of ANOVA in sentence length according to age group

\begin{tabular}{lrrrrrrr}
\hline & EC & \multicolumn{1}{c}{ LC } & Adc & YA & OA & Ed & $F$ \\
\hline MLU-m & $9.4(3.0)$ & $12.3(5.0)$ & $19.2(5.3)$ & $15.3(3.2)$ & $16.5(4.7)$ & $13.1(4.8)$ & $11.830^{* *}$ \\
MLU-w & $7.2(2.6)$ & $9.6(4.3)$ & $14.7(4.2)$ & $11.6(2.7)$ & $12.4(3.5)$ & $10.0(3.5)$ & $10.265^{* *}$ \\
MLU-c & $5.1(2.1)$ & $6.2(2.6)$ & $9.8(2.7)$ & $7.5(1.4)$ & $8.6(2.5)$ & $6.3(2.5)$ & $10.523^{* *}$ \\
MSL & $11.1(3.3)$ & $13.6(5.0)$ & $20.0(5.1)$ & $16.7(3.9)$ & $17.9(4.4)$ & $14.4(5.0)$ & $10.004^{* *}$ \\
\hline
\end{tabular}

Values are presented as mean (SD).

$\mathrm{EC}=$ early childhood (preschooler); $\mathrm{LC}=$ late childhood (school aged child); $\mathrm{Adc}=$ adolescent; $Y \mathrm{~A}=$ young adult; $\mathrm{OA}=$ older adult; $E d=$ elderly; $\mathrm{MLU}-\mathrm{m}=$ mean length of utterance in morphemes; MLU-w= mean length of utterance in words; MLU-c=mean length of utterance in clutters; $M S L=$ mean syntactic length. ${ }^{* *} p<.001$.

Table 5. Result of post-hoc analysis on sentence length

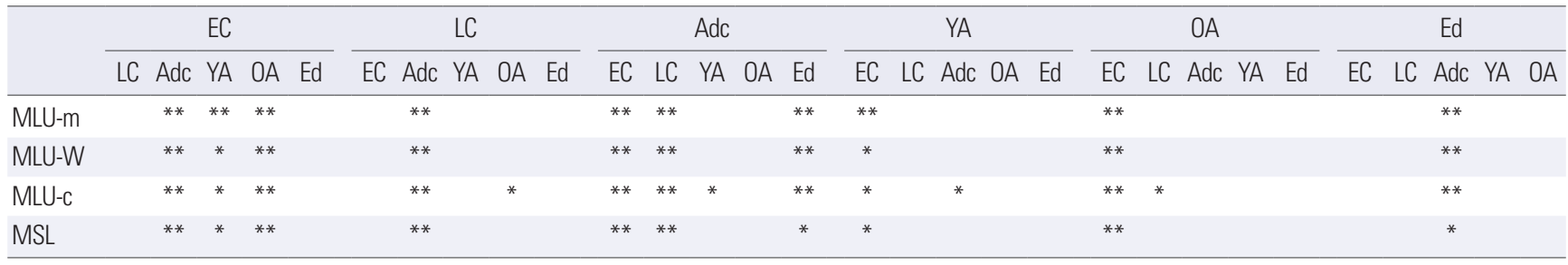

$\mathrm{EC}=$ early childhood (preschooler); $\mathrm{LC}=$ late childhood (school aged child); $\mathrm{Adc}=$ adolescent; $Y \mathrm{~A}=$ young adult; $\mathrm{OA}=$ older adult; $E d=$ elderly; $M L U-\mathrm{m}=$ mean length of utterance in morphemes; MLU-w=mean length of utterance in words; $M L U-c=$ mean length of utterance in clutters; $M S L=$ mean syntactic length.

${ }^{*} p<.05,{ }^{* *} p<.001$.
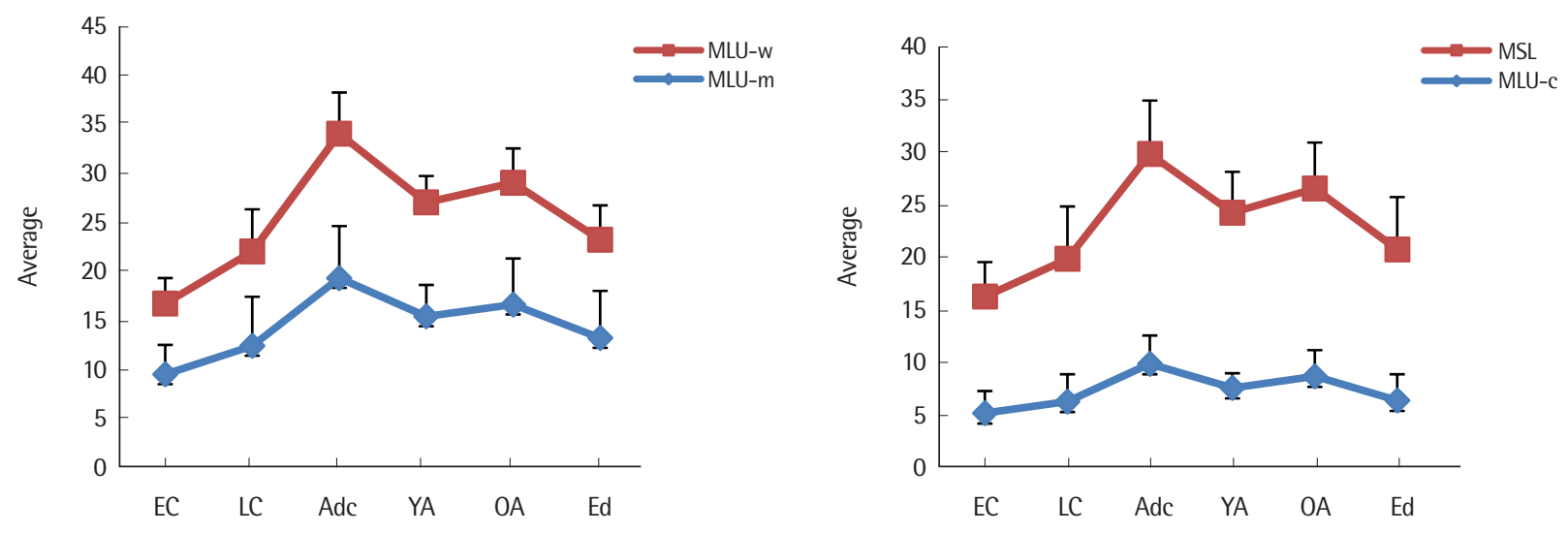

Figure 2. Analysis of sentence length characteristic to age.

$\mathrm{EC}=$ early childhood (preschooler); $\mathrm{LC}=$ late childhood (school aged child); $\mathrm{Adc}=$ adolescent; $Y \mathrm{~A}=$ young adult; $\mathrm{OA}=$ older adult; $\mathrm{Ed}=\mathrm{elderly;} \mathrm{MLU}-\mathrm{m}=\mathrm{mean}$ length of utterance in morphemes; MLU-W= mean length of utterance in words; MLU-c=mean length of utterance in clutters; $M S L=$ mean syntactic length. 
노년기에 비해 단문 사용률이 유의하게 낮았으며, 노년기는 후기아 동기와 청소년기보다 높은 단문 사용률을 보였고, 후기성인기는 다 른 집단 간의 유의한 차이가 나타나지 않았다.

복문 비율은 단문 비율과는 반대로 초기아동기부터 청소년기까 지 증가되었다가 초기성인기에 감소한 후 후기성인기에 다시 증가하 였다가 노년기에 가장 크게 감소하였다. ANOVA를 통해 연령 집단 간의 차이를 검정한 결과, 유의미하게 차이 $\left(F_{(5,114)}=8.970, p<.001\right)$ 를 보였다. Bonferroni 사후분석 결과, 초기아동기는 후기아동기와 청소년기에 비해 복문 사용률이 낮았고, 후기아동기는 초기아동기 와 노년기보다 높은 복문 사용률을 보였다. 또한 청소년기는 초기 아동기, 초기성인기, 노년기에 비해 복문 사용률이 유의하게 높았 으며, 노년기는 후기아동기와 청소년기보다 낮은 복문 사용률을 보 였고, 후기성인기는 다른 집단 간의 유의한 차이가 나타나지 않았 다. 구문 유형 지표에 따른 통계분석 결과는 Tables 6과 7, Figure 3 과같다.

\section{구문 측정치를 통한 집단 판별 분석 결과}

구문 분석 지표의 변인 중 각 집단의 특성을 판별할 수 있는 판별 함수를 확인하고 독립변수의 상대적 기여도를 파악하기 위해 단계 식 판별분석(stepwise estimation-discriminate analysis)을 실시하 였다. 연령 집단 간 유의미한 차이를 보인 전체문장수, 발화당 음절 수, 발화당 어미수, 발화당 조사수, 발화당 문법기능어수, 평균형태 소길이, 평균낱말길이, 평균어절길이, 평균구문길이, 단문 비율, 복 문 비율의 총 11 개의 종속 측정치를 입력하여 판별 분석을 실시한 결과, 도출된 각 측정치들은 연령 집단을 유의미하게 판별해주는 요인으로 확인되었으며 (eigenvalue $=.793$, 정준상관계수 $=.665$, Wilks' $\lambda=.255, \chi^{2}=152.929, p<.001$ ), 구조행렬(structure matrix) 을 통해 구문 측정치 간의 상대적 중요도를 살펴본 결과, 발화당 어 미수(.807), 발화당 기능어수(.733), 평균형태소길이(.713), 평균구 문길이(.665), 평균낱말길이(.649), 평균어절길이(.645), 발화당 음절 수(.640), 발화당 조사수(.528), 전체문장수(.488) 순으로 연령 집단 구분에 기여하는 것으로 나타났다.

Table 6. Result of ANOVA in sentence type according to age group

\begin{tabular}{lccccccc}
\hline & EC & LC & Adc & YA & OA & Ed & $F$ \\
\hline Simple sentence (\%) & $59.5(17.9)$ & $40.5(18.3)$ & $30.0(18.1)$ & $51.9(10.6)$ & $45.5(19.7)$ & $60.7(19.3)$ & $8.970^{* *}$ \\
Complex sentence $(\%)$ & $40.4(17.9)$ & $59.4(18.3)$ & $69.9(18.1)$ & $48.0(10.6)$ & $54.5(19.7)$ & $39.2(19.3)$ & $8.970^{* *}$ \\
\hline
\end{tabular}

Values are presented as mean (SD).

$\mathrm{EC}=$ early childhood (preschooler); $\mathrm{LC}=$ late childhood (school aged child); $\mathrm{Adc}=$ adolescent; $Y \mathrm{~A}=$ young adult; $\mathrm{OA}=$ older adult; $\mathrm{Ed}=$ elderly. ${ }^{* *} p<.001$.

Table 7. Result of post-hoc analysis on sentence type

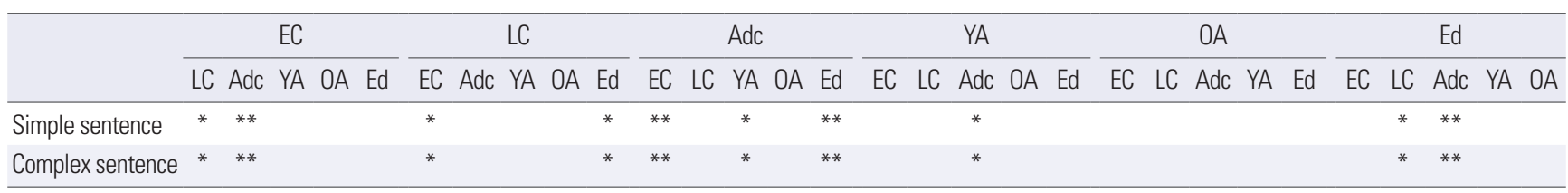

$\mathrm{EC}=$ early childhood (preschooler); $\mathrm{LC}=$ late childhood (school aged child); $\mathrm{Adc}=$ adolescent; $Y \mathrm{~A}=$ young adult; $\mathrm{OA}=$ older adult; $\mathrm{Ed}=$ elderly. ${ }^{*} p<.05,{ }^{* *} p<.001$.
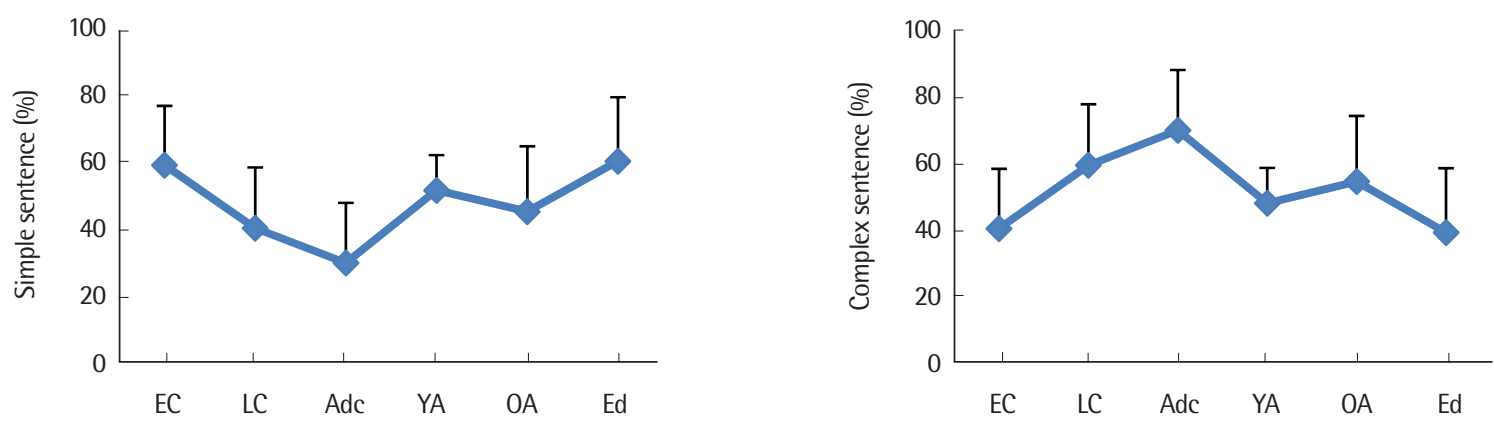

Figure 3. Analysis of sentence type characteristic to age.

$\mathrm{EC}=$ early childhood (preschooler); $\mathrm{LC}=$ late childhood (school aged child); $\mathrm{Adc}=$ adolescent; $Y \mathrm{~A}=$ young adult; $\mathrm{OA}=$ older adult; $\mathrm{Ed}=$ elderly. 


\section{논의 및 결론}

\section{구문 산출 특성}

구문 산출 특성의 측면에서는 '전체문장수, 발화당 음절수, 발화 당 조사수, 발화당 어미수, 발화당 문법기능어수를 측정하였다. 구 문 능력의 양적 지표가 되는 전체문장수와 발화당 음절수의 경우, 초기 아동 집단은 청소년기에 비해 적은 문장수와 음절수를 산출 하였고, 노년기 집단은 청소년기 집단에 비해 적은 문장수와 음절 수를 산출하였다. 이러한 결과는 낱말 조합을 통해 구문으로의 초 기 발달이 이루어지는 초기아동기를 지나 청소년기까지의 시기를 대상으로 한 선행연구(Kim \& Kim, 2011)에서 구문 산출 능력을 확인하기 위해 전체 T-unit과 전체 낱말수를 분석하였을 때 학년이 올라감에 따라 양적으로 증가하는 양상을 보인 결과와 일치하는 양상을 보여준다. 그러나 초기성인기에서 노년기에 이르며 수행이 저하되는 양상은 선행연구(Choi, 2012; Lee \& Kim, 2001)의 결과와 는 다소 상이하였다. 선행연구에서는 연령 집단 21-44세, 45-64세, 65세 이상의 세 집단 간 발화당 음절수(Lee \& Kim, 2001)에서 서로 차이가 없었으며, 20 대의 청년과 65 세 노년층의 전체문장수(Choi, 2012)에서도 유의미한 차이가 나타나지 않았다. 이러한 결과의 차 이는 연구에 사용된 과제의 차이에 기인하였을 가능성이 있다. 본 연구에서는 주제에 따른 반구조적인 대화 절차를 사용하여 대화 를 수집한 반면, 선행연구에서는 실어증 검사도구에 포함된 단답형 의 질문이나 제시된 그림을 보고 설명하는 과제를 사용하였다. 본 연구과제와 같이 하나의 주제에 대해 대화를 지속적으로 이어나가 기 위해서는 단순히 낱말을 조합하는 것뿐만 아니라 대화 맥락에 따라 의미와 문법적 요소를 바르게 결합하여 문장으로 산출해야 하므로 보다 많은 인지적 역량을 필요로 한다. 특히 노년기에는 인 지적 더딤(cognitive slowing)으로 인해 처리 속도 및 주의력이 저하 되고(Salthouse, 1996) 조작에 필요한 효율성이 감소되면서(Stine \& Wingfield, 1987) 처리 역량에 제약을 받기 쉽다. 따라서 본 결과는 인지적 부담이 가중되는 상황에서 노년층이 더 영향을 받았을 가 능성을 시사한다(James \& MacKay, 2001).

또 다른 관점으로 구문을 만들기 위해서는 조직된 문장을 검토 하는 이른바 상위언어능력이 필수적인데, 상위언어능력은 일반적 으로 의미, 음운, 구문에 대한 인식 순으로 습득하게 된다(Tunmer \& Bowey, 1984). 그러나 역발생 가설(retrogenesis hypothesis; Reisberg et al., 1999, 2002)에 따르면 습득의 역순으로 그 능력에 감퇴 를 보이게 되어 어린 나이에 습득한 정보는 유지되나 나중에 습득 한 정보는 먼저 퇴행하는 양상이 언어, 인지, 운동, 사회적 능력 등 다양한 방면에서 관찰되었다(Kim et al., 2011; Reisberg et al., 1999,
2002). 이와 같은 맥락으로 알츠하이머형 치매 환자와 정상아동의 이름대기 산출 능력을 비교한 연구(Kim et al., 2011)를 보면 치매 환자가 초기에 습득한 어휘는 비교적 잘 유지하였으나 나중에 습 득한 어휘는 먼저 퇴행되는 양상이 증명되었다. 물론 본 연구대상 자들은 정상 노년층이므로 선행연구 결과를 그대로 적용하기에는 한계가 있으나 한편으로는 인지장애가 없는 노화과정에서도 초기 에 습득된 의미 능력보다 비교적 후기에 습득된 구문 능력에서 더 많은 저하를 보일 수 있음을 보여준다(Park, 2015). 또한 동일한 대 상자로 진행된 선행연구(Lee et al., 2017)에서 전체 어휘수나 다른 어휘수 등 양적 측면의 어휘 사용 능력은 노년기에도 유지되는 양 상을 보였으나 본 연구의 전체문장수에서는 감퇴의 양상을 보인 것 을 통해 언어 영역별 변화의 양상이 상이하며 이는 나중에 습득한 구문 산출 능력의 감퇴에 기인한 것일 수 있겠다.

발화당 조사수, 발화당 어미수, 발화당 문법기능어수 또한 초기 아동기에서 청소년기까지 증가하다가 초기성인기에서 노년기까지 감소하는 추세를 보였다. 한 발화당 사용하는 조사, 어미, 문법기능 어는 완전한 구문을 이루기 위해 필수적인 요소가 될 뿐만 아니라 음절 및 문장수 증가에 영향을 주며 문장이 담고 있는 의도와 내용 이 보다 정교해질 수 있게 한다. 따라서 이러한 지표들은 구문의 양 적인 측면뿐만 아니라 질적인 측면을 반영하는 지표가 된다. 초기 아동기의 연결어미 발달 연구를 통하여 2;0-3;5세에는 연결어미의 산출 능력이 매우 낮았지만 3;6-4;5세에서는 어미가 활발히 발달하 다가 4;6세 이후에는 연결어미를 거의 정확하게 산출하는 것으로 나타나 연령의 증가에 따라 발화당 어미의 수가 증가하는 본 연구 결과와 일치하는 양상을 보였다(Seo \& Lee, 1999). 또한 2-7세 아동 을 대상으로 한 한국어의 문법형태소 습득에 관한 연구에서는 다 섯 가지 조사에 대한 이해 정도를 살펴보았는데 3 세의 경우 조사의 탐색이 활발하게 이루어지고 4 세의 경우 조사에 대한 이해 능력이 안정기에 접어 들면서 연령에 따라 조사의 이해가 증가되어(Pae, 1997) 본 연구의 발화당 조사의 수 양상과 유사하였다. 즉 조사와 어미에 대한 이해와 표현 능력이 연령에 따라 증가된다는 것은 조 사와 어미를 포함한 문법기능어수에도 영향을 주어 기능어수 또한 연령에 따라 증가된다는 것을 의미한다. 성인기의 경우에는 정상 노 년층의 문장에서 나타나는 구문 구조, 문장 분절 등의 구문 복잡성 을 분석한 연구에서 연령이 증가할수록 구문의 복잡성이 감소하여 본 연구결과와 일치하는 양상을 보였다(Kemper et al., 2001). 특히 노년기에는 인지기능의 변화로 인해 목표 정보로의 접근(access)과 활성화(activation)정도가 저하되고 앞서 언급된 청년층에 비해 처 리할 수 있는 역량이 적어(James \& Mackay, 2001) 보다 복잡한 구 문을 처리하는 데 어려움이 있기 때문에 반응시간 지연 및 에두르 
기와 같은 특성이 나타나기도 한다(Burke \& Shafto, 2004; Crossman \& Szafran, 1956). 따라서 이와 유사한 맥락에서 노년층은 다 양한 문법형태소가 포함된 복잡한 구문 구조를 표현하는 데 어려 움이 있는 것으로 해석해 볼 수 있겠다.

또한 이러한 결과는 언어를 사용하는 환경의 영향에 기인한 것 일 수 있다. 초기/후기아동기를 지나 학령기에서 청소년기로 갈수 록 배움을 위한 학습의 중요성이 강조되기 때문에 읽기 및 쓰기 등 의 문어 사용이 증가된다(Hadley, 1998; Scott, 1988a). 따라서 문법 형태소가 습득되고 사용되는 환경의 변화가 있을 수 있다. 이와는 반대로 구어 의사소통 상황에서는 특정 문법형태소가 생략되는 것 이 용인되기도 하며 문법형태소 없이도 의미가 전달될 수 있으므로 (예: /나 학교 가/) 상대적으로 문어의 환경보다는 적은 문법형태소 를 사용할 수 있다. 따라서 후기아동기에 해당하는 학령기 및 청소 년기에는 학습을 통해 문어 양식 속에서 문법형태소의 사용이 활 발하게 이루어지지만(Nelson, 2010; Scott, 2009) 그 이후 시기에서 는 상대적으로 구어 사용 환경에 더 익숙해지면서 문법형태소의 사용이 줄어든 것으로 해석해 볼 수 있겠다.

\section{구문 길이 특성}

구문 길이 특성의 측면에서는 평균형태소길이, 평균낱말길이, 평 균어절길이, 평균구문길이 모두 아동기부터 청소년기까지 증가한 후 초기성인기부터 노년기까지는 감소하는 추세를 보였다.

전통적으로 평균발화길이(MLU)의 증가는 문법형태소의 발달 과 구문의 복잡성이 증가한다는 것을 의미하므로(Jung \& Yoon, 2013) 아동기의 구문 발달을 파악하는 민감한 척도로서 사용되었 다(Kim, 1997; Kim, 2014; Rice et al., 2010; Thordardottir \& Wesimer, 1998). 초기아동기를 지나 후기아동기 및 청소년기로 나아가 면서부터는 문법을 오랜 기간 동안 세련되게 발달시키게 되는데 (Nippold, 1998; Scott, 1988b) 이 연령 단계가 되면 평균발화길이 $(\mathrm{MLU})$ 는 구문 길이 및 복잡성 등의 지표로서 효과가 크지 않으므 로(Paul \& Norbury, 2007) 홑문장 및 주절에 결합된 종속절을 포 함하는 단위로서 구문 능력을 반영해주는 T-unit (최소종결단위) 을 대신 사용한다(Lee \& Kwon, 2002; as cited in Paul \& Norbury, 2007; Yim et al., 2008). 이에 본 연구결과는 아동기의 생활연령이 증가됨에 따라 $\mathrm{MLU}$ 가 증가한다는 결과(Brown, 1973; Casby, 2011; Kim, 1997; Miller \& Chapman, 1981; Rice et al., 2010; Thordardottir \& Weismer, 1998)와 일치하였다. 또한 T-unit을 사용하 여 살펴본 초등학생 $1,3,5$ 학 년을 대상으로 한 연구(Jin \& Pae, 2008)에서도 인터뷰 형식의 대화와 그림보고 이야기하기 과제를 통해 발화를 수집하고 T-unit을 분석하였는데, 그 결과 MLT-w,
MLT-m에서 유의미한 차이를 보이면서 학년이 증가할수록 T-unit 의 길이와 복잡성이 증가하여 본 결과와 일치하는 양상을 보였다. 6-8세 아동을 대상으로 한 연구(Yun, 2008)에서도 연령에 따라 MLC-w 값이 증가하였고 초등학교 4, 6학년과 중학교 2학년 학생 집단에서도 학년이 올라감에 따라 MLT-w가 증가하여 본 연구와 일치하였다. 그러나 이야기 다시 말하기 방법을 통해 학령기 6-10세 아동의 T-unit을 살펴본 연구에서는 T-unit당 낱말의 평균수가 6;0-6;5 집단과 8;0-8;5 집단 간 유의미한 차이를 보였으나, 8;0-8;5 집단과 10;0-10;5 집단 사이에는 차이가 나타나지 않았다. 이러한 이유는 발화수집 유형과 담화 유형에 따라 문법표현에 영향을 주 기도 하므로(Lee et al., 2008; Lee \& Kwon, 2002; Scott \& Windsor, 2000) 결과에 영향을 준 것으로 생각해 볼 수 있다.

한편, 성인기 이후의 연령 집단에서는 구문 능력을 확인하는 지 표로서 구문 길이보다는 CIU와 같은 지표들을 활용하는 경우가 많아(Choi, 2014; Kwon et al., 1998; Jeon \& Kim, 2015; Lee, et al., 2011) 본 연구결과와 직접적인 비교가 어렵다. 그러나 연령의 증가 에 따라 구문 복잡성이 감소하고(Kemper et al., 2001; Lee \& Kim, 2005; Shin, Hwang, \& Lim, 2018) 문법형태소 오류를 빈번하게 보 인다는 연구결과(Bock \& Levelt, 2002; Burke, MacKay, \& James, 2000; Park, 2015)를 통해 문법형태소의 활용이 원활하지 않을 때 보다 단순한 문장을 사용하면서 구문의 길이가 감소되는 것으로 예측하여 볼 수 있겠다.

신경생리학점 관점과 결부하여 살펴보았을 때 초기아동기 시기 부터 회백질의 용적과 두께가 꾸준히 성장하면서(Gogtay et al., 2004) 신경 연접이 활발해지게 되어 청소년기인 12-14세 기점에는 최대치로 증가되다가(Jernigan, Trauner, Hesselink, \& Tallal, 1991; Sowell et al., 2003) 그 이후에는 노화에 따른 퇴행 등으로 회백질의 부피가 감소하는 양상을 보이게 된다(Park \& Kim, 2011; Park \& $\mathrm{Kim}, 2015)$. 따라서 다양한 문법형태소 습득과 의미 간의 기능적 연결이 가능해지면서 구문 길이가 청소년기까지 증가하다가 성인 기 이후 노화에 접어들면서 결과적으로 구문의 길이가 줄어든 것 으로 해석해 볼 수 있다. 또 다른 측면으로는 전두엽 기능과 결부시 켜 볼 수 있다. 구문을 형성하기 위해선 통사의 정보를 처리하거나 구문적 형식을 구조화시켜야 하는데(Crossman \& Szafran, 1956) 이러한 능력은 전두엽이 처리한다. 전두엽 기능 중 작업기억(Baddeley, 1993)은 문장을 산출하면서 동시에 정보를 유지시키며 조작 한다. 따라서 노년기에는 복잡한 절차가 수반되는 작업기억 관련 인지처리 과정이 더 취약해지면서(Burke \& Shafto, 2004; Just \& Carpenter, 1992; Kemper, 1997) 보다 단순한 구문 구조를 선호하 게 되고 결국 이는 구문 길이의 감소로 이어지는 것으로 해석해 볼 
수 있는 동시에(Kemper et al., 2001) 발달의 감퇴가 가장 큰 전두엽 기능을 통해 구문 능력에 대한수행력이 예측될수 있음을 시사한다.

\section{구문 유형 특성}

구문 유형 측면에서는 단문 비율의 경우 초기아동기는 후기아동 기와 청소년기에 비해 단문 사용률이 높았고, 청소년기는 초기아동 기, 초기성인기, 노년기에 비해 단문 사용률이 유의하게 낮았으며, 노년기는 후기아동기와 청소년기보다 높은 단문 사용률을 보였으 며 복문의 비율은 단문 비율의 결과와 반대되는 결과를 보였다. 일 반적으로 2 세와 3 세 사이에는 주어와 서술어의 관계가 한 번인 단 문들을 조합하여 이어진 문장을 만들기 시작하고 기초 구문을 갖 춘다(Bloom, Lahey, Hood, Lifter, \& Fiess, 1980; Crystal, 1987). 본 결 과는 초기아동기에 문법적으로 다양하고 보다 복잡한 복문 구조 를 시도할 수 있게 되고 성인과의 의사소통 어려움이 없을 정도의 언어적 성취를 보인다는 선행연구(Lee \& Lee, 2010)와 일치하며 단 문의 사용이 청소년기까지 지속적으로 감소하는 반면 복문의 비율 은 아동기부터 청소년기까지 증가한다는 연구결과(Scott \& Stokes, 1995)와도 일치한다. 또한 학령기에 속하는 후기아동기에서 청소년 기까지는 명사절, 부사절, 관형절의 종속절 등의 수가 증가되고 종 속절의 유형별 사용률 또한 증가하면서 복문의 사용이 증가되는 결과와도 맥락을 같이한다(Jin \& Pae, 2008; Kwon \& Pae, 2006;

Lee, 2009; Loban, 1976; Nippold et al., 2005; Nippold, 2007; Yim et al., 2008).

노년층의 경우에도 청년층에 비해 유효한 정보를 산출하는 종속 절의 수가 적어 발화 내 구문복잡성이 저하된다는 연구결과와 일 치하였는데(Shin et al., 2018) 이러한 결과는 단문과 복문이 가지는 언어적 특성 차이와 관련지어 해석해 볼 수 있다. 단문은 주어와 서 술어의 관계가 한번만 나타나는 문장으로 대체로 문장의 길이가 짧을 뿐만 아니라 그 구조가 단순하다. 그러나 복문은 주어와 서술 어의 관계가 두 번 이상 나타나는 문장으로 그 안에 주어와 서술어 의 관계가 완결되지 않은 절을 포함한다(Yi, 2015). 복문을 구성하 기 위해서는 단문이 다른 문장 안에 문장성분으로 포함되는 '내포' 의 방법과 단문을 연속해서 연결하는 '접속'에 대한 활용이 필요하 다. 예를 들어, /형은 말했다/와/철수는 학교에 간다/라는 단문을 사용하여 복문으로 만들 경우 /형은 철수가 학교에 간다고 말했다/ 와 같이 인용절을 내포하여 복문으로 만들거나 /여름에는 비가 내 린다/와 /겨울에는 눈이 내린다/를 사용하여 복문으로 만들 경우 대등적 연결어미 '-고'를 사용하여 /여름에는 비가 내리고 겨울에는 눈이 내린다/로 만들 수 있다. 이처럼 단문을 복문으로 변형시키기 위해서는 '어미'와 ‘조사'의 활용이 필수적이다. 따라서 단문과 복문
의 사용 비율에 대한 양상은 앞서 논의하였던 발화당 조사수, 어미 수, 문법기능어수 사용 능력과 유사한 변화 양상을 보인 것이라 해 석할수 있다.

\section{연령 집단 판별 요인}

각 연령 집단의 특성 구분에 기여하는 지표를 확인하였을 때, 발 화당 어미수가 집단을 가장 의미 있게 분류하는 것으로 나타났으 며, 어미와 조사를 합산한 발화당 기능어수, 평균형태소, 구문, 낱 말, 어절 길이의 순으로 나타났다. 일반적으로 평균발화길이는 4세 까지는 연령과 상관관계가 높아 MLU가 차지하는 가치가 크지만 이후에는 MLU에 영향을 미치는 변수나 개인차가 많이 존재한다 (De Villiers \& De Villiers, 1973; Miller \& Chapman, 1981). 따라서 이러한 결과는 다양한 연령의 담화 능력을 확인할 때는 구문의 길 이를 반영하는 지표(구문길이, 낱말길이)뿐만 아니라 앞서 논의한 것과 같이 구문의 질적인 측면을 반영하는 어미나 기능어를 중요하 게 살펴보아야함을 시사한다.

본 연구결과를 종합해 보면, 구문 산출, 길이, 유형의 지표들이 전반적으로 초기아동기에서 후기아동기를 거쳐 청소년기까지 그 수치가 증가하다가 청소년기 이후를 기점으로 점차 감소하여 일부 지표에서는 노년기에 초기아동기와 유사한 정도로 저하되는 양상 을 확인할 수 있었다. 그리고 뇌의 구조적 성장은 청소년기에 정점 에 이른 후 퇴화하며, 특히 전두엽의 피질 두께가 다른 영역에 비하 여 더 많이 감소할 뿐만 아니라 더 이른 시기인 25-58세의 연령 집 단에서부터 변화하기 시작한다(Park \& Kim, 2011; Park \& Kim, 2015). 따라서 이러한 결과는 뇌의 발달과 변화 과정이 단어를 조합 하고 문법형태소를 첨가하여 완전한 형태의 문장을 산출하는 구 문 능력 전반에 영향을 주었을 가능성을 시사한다.

본 연구는 전생애적 관점에서 구문 능력의 발달 능력을 확인하 기 위하여 특정 연령대가 아닌 초기아동기부터 노년기까지 아우르 는 언어 발달 경향을 살펴본 최초의 연구로서 각 연령대를 구별해 주는 구문 지표를 제시하였다는 점에서 임상적 의의가 있다. 연구 절차 측면에서는 대화상황에서 구조화된 검사 절차를 통해 대상자 가 가진 자연스러운 발화를 수집하여 객관적이면서도 구문 구조의 특성을 최대한 반영하고자 하였다. 그러나 전생애 발달을 보기 위 해 모든 연령 집단에게 동일한 지표를 사용하였기 때문에 특정 집 단에게 다소 적절하지 않은 분석치(예: MLU)가 적용된 것은 본 연 구의 제한점이다. 추후 연구에서는 전 연령대를 아우를 수 있는 지 표들을 재고하는 과정도 중요하겠다. 마지막으로 각 연령 집단별 대상자 수가 충분치 않아 본 연구결과로 각 집단을 대표하는 구문 특성을 확립하기 어려우며, 구문 측정치 수와 비교해서도 대상자 
수가 충분하게 고려되지 않았으므로 판별 분석 결과의 해석에 주 의가 필요하다. 앞으로는 충분한 사례 수를 통하여 각 연령 집단을 대표하고 구별하는 구문 지표를 확인하고, 뇌영상 자료와의 상관 분석을 통하여 각 지표가 뇌의 신경생리학적 발달과 어떠한 관계 가 있는지 확인할 수 있다면 구문 능력과 관련한 뇌 기능의 발달과 감퇴 시기를 예측할 수 있을 것이다. 더불어 특정 구문 지표에 대한 예측은 언어장애 환자뿐만 아니라 노화로 인한 의사소통장애의 증상 감별을 위한 초석이 될 수 있을 것이다.

\section{REFERENCES}

Andersen, B. B., Korbo, L., \& Pakkenberg, B. (1992). A quantitative study of the human cerebellum with unbiased stereological techniques. Journal of Comparative Neurology, 326, 549-560.

Ardila, A., \& Rosselli, M. (1996). Spontaneous language production and aging: sex and educational effects. International Journal of Neuroscience, 87, 71-78.

Baddeley, A. (1993). Working memory and conscious awareness. In A. F. Collins et al. (Eds.), Theories of memory (pp. 11-20). Hove, UK: Lawrence Erlbaum Associates.

Baltes, P. B. (1987). Theoretical propositions of life-span developmental psychology: on the dynamics between growth and decline. Developmental Psychology, 23, 611-626.

Bloom, L., \& Lahey, M. (1978). Language development and language disorders. New York, NY: John Wiley \& Sons.

Bloom, L., Lahey, M., Hood, L., Lifter, K., \& Fiess, K. (1980). Complex sentences: acquisition of syntactic connectives and the semantic relations they encode. Journal of Child Language, 7, 235-261.

Bock, K., \& Levelt, W. (1994). Language production: grammatical encoding. In M. A. Gernsbacher (Ed.), Handbook of psycholinguistics (pp. 945-984). San Diego, CA: Academic Press.

Brown, R. (1973). A first language: the early stages. Cambridge, MA: Harvard University Press.

Burke, D. M., \& Shafto, M. A. (2004). Aging and language production. Current Directions in Psychological Science, 13, 21-24.

Burke, D. M., MacKay, D. G., \& James, L. E. (2000). Theoretical approaches to language and aging. In T. J. Perfect \& E. A. Maylor (Eds.), Models of cognitive aging (pp. 204-237). New York, NY: Oxford University Press.

Casby, M. W. (2011). An examination of the relationship of sample size and mean length of utterance for children with developmental language im- pairment. Child Language Teaching and Therapy, 27, 286-293.

Choi, H. J. (2012). Discourse characteristics in healthy elderly: effects of aging, gender and educational level. Phonetics and Speech Sciences, 4, 135143.

Choi, H. J. (2014). The relationship between demographic factors and expressive language ability to correct information units in healthy senior citizens. Journal of Speech \& Hearing Disorders, 23, 51-60.

Christensen, K. J., Multhaup, K. S., Nordstrom, S., \& Voss, K. (1991). A cognitive battery for dementia: development and measurement characteristics. Psychological Assessment: A Journal of Consulting and Clinical Psychology, 3, 168-174.

Crossman, E. R., \& Szafran, J. (1956). Changes with age in the speed of information-intake and discrimination. Experientia, (Suppl 4), 128-135.

Crystal, D. (1987). Child language, learning and linguistics (2nd ed.). London: Arnold.

Cummings, J. L. (1993). Frontal-subcortical circuits and human behavior. Archives of Neurology, 50, 873-880.

Damasio, A. R., \& Anderson, S. W. (1993). The frontal lobes. In K. M. Heilman \& E. Valenstein (Eds.), Clinical neuropsychology (3rd ed., pp. 409-460). New York, NY: Oxford University Press.

De Villiers, J. G., \& De Villiers, P. A. (1973). A cross-sectional study of the acquisition of grammatical morphemes in child speech. Journal of Psycholinguistic Research, 2, 267-278.

Duffy, J. D., \& Campbell, J. J. (1994). The regional prefrontal syndromes: a theoretical and clinical overview. The Journal of Neuropsychiatry and Clinical Neurosciences, 6, 379-387.

Filley, C. M. (1995). Neurobehavioral anatomy. Niwot, CO: University Press of Colorado.

Gibson, E. (1998). Linguistic complexity: locality of syntactic dependencies. Cognition, 68, 1-76.

Gogtay, N., Giedd, J. N., Lusk, L., Hayashi, K. M., Greenstein, D., Vaituzis, A. C., ... \& Rapoport, J. L. (2004). Dynamic mapping of human cortical development during childhood through early adulthood. Proceedings of the National Academy of Sciences, 101, 8174-8179.

Ha, J. W., Jung, Y. H., \& Sim, H. S. (2009). The functional characteristics of fillers in the utterances of dementia of Alzheimer's type, questionable dementia, and normal elders. Communication Sciences \& Disorders, 14, 514530 .

Hadley, P. A. (1998). Language sampling protocols for eliciting text-level discourse. Language, Speech, and Hearing Services in Schools, 29, 132-147. 
Havighurst, R. J. (1973). History of developmental psychology: socialization and personality development through the life span. In P. B. Baltes \& K. Warner Schaie (Eds.), Life-span developmental psychology (pp. 3-24). New York, NY: Academic Press.

Hwang, S. T., Kim, J. H., Park, K. B., Choi, J. Y., \& Hong, S. H. (2012). KoreanWechsler Adult Intelligence Scale IV (K-WAIS-IV). Seoul: Hakjisa.

James, L. E., \& MacKay, D. G. (2001). HM, word knowledge, and aging: upport for a new theory of long-term retrograde amnesia. Psychological Science, 12, 485-492.

Jeon, Y. M., \& Kim, W. S. (2015). Characteristics of the discourse according to each age group and task type. Journal of Rehabilitation Research, 19, $297-$ 320.

Jernigan, T. L., Trauner, D. A., Hesselink, J. R., \& Tallal, P. A. (1991). Maturation of human cerebrum observed in vivo during adolescence. Brain, 114, 2037-2049.

Jin, Y. S., \& Pae, S. Y. (2008). Grammatical ability of school-aged Korean children. Journal of Speech \& Hearing Disorders, 17, 1-16.

Jung, Y. H., \& Yoon, M. (2013). Mean length of utterance for typically developing children of 2 to 4 years. Korean Journal of Early Childhood Special Education, 3, 55-73.

Just, M. A., \& Carpenter, P. A. (1992). A capacity theory of comprehension: individual differences in working memory. Psychological Review, 99, 122149.

Kang, Y. (2006). A normative study of the Korean-Mini Mental State Examination (K-MMSE) in the elderly. Korean Journal of Psychology: General, $25,1-12$.

Kemper, S. (1997). Metalinguistic judgments in normal aging and Alzheimer's disease. The Journals of Gerontology Series B: Psychological Sciences and Social Sciences, 52, P147-P155.

Kemper, S., Thompson, M., \& Marquis, J. (2001). Longitudinal change in language production: effects of aging and dementia on grammatical complexity and propositional content. Psychology and Aging, 16, 600-614.

Kim, H. A., Won, S. R., Lee, B. E., \& Yoon, J. H. (2017). Characteristics of narrative writing in normal aging: story grammar and syntactic structure. Journal of Rehabilitation Research, 21, 193-212.

Kim, H. G. (2001). Clinical evaluation of the frontal lobe syndrome using Kims frontal-executive neuropsychological test. Journal of Rehabilitation Psychology, 8, 173-190.

Kim, H., Yoon, J. H., Lee, J. E., Baek, E. J., Sohn, Y. H., \& Na, D. L. (2011). Is confrontation naming performance in Alzheimer's disease the nominal linguistic retrogenesis of normal development? European Neurology, 66, 195-199.

Kim, J. S., \& Kim, J. M. (2011). Characteristics of syntactic ability of schoolage children and adolescents in expository and narrative tasks. Korean Journal of Communication \& Disorders, 16, 540-558.

Kim, J. W., \& Kim, H. H. (2009). The characteristics of Korean morpheme production in Alzheimer's patients. Journal of Speech \& Hearing Disorders, 18, 75-90.

Kim, J., Kim, H., Namkoong, K., Kim, S., \& Kim, D. (2006). Spontaneous speech traits in patients with Alzheimer's disease. Korean Journal of Communication \& Disorders, 11, 82-98.

Kim, Y. T. (1997). A preliminary study for mean length of utterance by Korean 2-4 ages children. Korean Journal of Communication Disorders, 2, 5-26.

Kim, Y. T. (2014). Assessment and treatment of language disorders in children (2nd ed.). Seoul: Hakjisa.

Kim, Y. T., Hong, G. H., Kim, K. H., Jang, H. S., \& Lee, J. Y. (2009). Receptive \& expressive vocabulary test (REVT). Seoul: Seoul Community Rehabilitation Center.

Koo, S., \& Choi, H. (2015). Characteristics of spontaneous speech in Broca’s aphasic patients through interview and picture description tasks. Journal of Rehabilitation Research, 19, 281-296.

Kwon, E., \& Pae, S. Y. (2006). Three measures of narrative discourse ability for Korean school-aged children in a story-retelling task. Korean Journal of Communication \& Disorders, 11, 72-89.

Kwon, M., Kim, H., Choi, S. S., Na, D., \& Lee, K. H. (1998). A study for analyzing spontaneous speech of Korean adults with CIU scoring system. Korean Journal of Communication \& Disorders, 3, 35-49.

Lahey, M. (1988). Language disorders and language development. New York, NY: Macmillan.

Lee, E., \& Kim, J. (2012). The relationship of mazes, utterance length and syntactic complexity in preschool children's spontaneous speech. Journal of Speech-Language \& Hearing Disorder, 21, 174-190.

Lee, H. J., Kim, Y. T., \& Yun, H. R. (2008). Characteristics of syntactic complexity in school-aged children with specific language impairment: a comparison of conversation and expository discourses. Korean Journal of Communication \& Disorders, 13, 103-121.

Lee, H. J., Park, C. I., Park, E. S., \& Kim, H. H. (2003). A study on the relationship between the children's development of predicates and syntactic ability. Korean Journal of Communication Disorders, 8, 20-40.

Lee, H. R. (2010). Development of sentence structures in Korean children 
age of 3-6 years. Journal of Speech \& Hearing Disorders, 19, 179-192.

Lee, H. R., \& Lee, S. (2010). Development of cohesive devices in preschool Korean children. Korean Journal of Communication \& Disorders, 15, 298306.

Lee, J. H. (2009). Syntactic development of school-aged children in conversation and story retelling task (Master's thesis). Nazarene University, Cheonan, Korea.

Lee, K. H., \& Kwon, D. H. (2002). A study of semantic and syntactic structure development of school-aged students by the story retelling. Journal of Speech \& Hearing Disorders, 11, 93-116.

Lee, M. S., \& Kim, H. H. (2005). Literacy-related syntactic characteristics of spontaneous speech in the normal elderly population. Korean Journal of Communication \& Disorders, 10, 1-11.

Lee, O. B., Park, S. H., \& Son, E. N. (2011). A correct information unit to describe the spontaneous speech of older and younger adults. Journal of Speech and Hearing Research, 20, 111-123.

Lee, Y., \& Choi, J. (in press). Hallym Conversation and Pragmatic Assessment Protocol. Manuscript in preparation.

Lee, Y. M., \& Kim, H. (2001). An utterance analysis of conversations and picture description tasks of Korean adults. Korean Journal of Communication Disorders, 6, 1-11.

Lee, Y., Choi, J., Yoon, J. H., Kim, Y. S., Min, J. S., \& Kim, J. (2017). Lifespan development of word use from early childhood to old age. Korean Journal of Communication \& Disorders, 22, 717-729.

Loban, W. (1976). Language development: kindergarten through grade twelve. Urbana, IL: National Council of Teachers.

Mackenzie, C. (2000). Adult spoken discourse: the influences of age and education. International Journal of Language \& Communication Disorders, 35, 269-285.

Mega, M. S., \& Cummings, J. L. (1994). Frontal-subcortical circuits and neuropsychiatric disorders. The Journal of Neuropsychiatry and Clinical Neurosciences, 6, 358-370.

Miller, J. F., \& Chapman, R. S. (1981). The relation between age and mean length of utterance in morphemes. Journal of Speech, Language, and Hearing Research, 24, 154-161.

Nelson, N. W. (2010). Language and literacy disorders: infancy through adolescence. Boston, MA: Allyn \& Bacon.

Nippold, M. A. (1998). Later language development: the school-age and adolescent years. Austin, TX: Pro-Ed.

Nippold, M. A. (2007). Later language development: school-age children, ado- lescents, and young adults (3rd ed.). Austin, TX: Pro-Ed.

Nippold, M. A., Hesketh, L. J., Duthie, J. K., \& Mansfield, T. C. (2005). Conversational versus expository discourse: a study of syntactic development in children, adolescents, and adults. Journal of Speech, Language, and Hearing Research, 48, 1048-1064.

Pae, S. Y. (1997). A study on acquisition of grammatical morphemes of Korean children. Korean Journal of Communication \& Disorders, 2, 27-42.

Park, J. H., \& Kim, S. H. (2011). Development of the adolescent brain and behavioral and cognitive characteristics. Journal of the Korean Society of Biological Therapies in Psychiatry, 17, 11-20.

Park, S. (2015). Cognitive aging and language: a psycholinguistic approach. Modern Korean Grammar Studies, 83, 25-39.

Park, Y., \& Kim, S. (2015). The effects of age, gender and head size on the cortical thickness of brain. Korean Journal of Biological Psychiatry, 22, 118127.

Paul, R., \& Norbury, C. F. (2007). Language disorders from infancy through adolescence: assessment \& intervention (3rd ed.). St. Louis, MO: Mosby.

Paul, R., \& Norbury, C. F. (2012). Language disorders from infancy through adolescence: assessment \& intervention (4th ed.). St. Louis, MO: Mosby.

Reed, V. A., Griffith, F. A., \& Rasmussen, A. F. (1998). Morphosyntactic structures in the spoken language of older children and adolescents. Clinical Linguistics \& Phonetics, 12, 163-181.

Reisberg, B., Franssen, E. H., Hasan, S. M., Monteiro, I., Boksay, I., Souren, L. E., ... \& Kluger, A. (1999). Retrogenesis: clinical, physiologic, and pathologic mechanisms in brain aging, Alzheimer's and other dementing processes. European Archives of Psychiatry and Clinical Neuroscience, 249, S28S36.

Reisberg, B., Franssen, E. H., Souren, L. E., Auer, S. R., Akram, I., \& Kenowsky, S. (2002). Evidence and mechanisms of retrogenesis in Alzheimer's and other dementias: management and treatment import. American Journal of Alzheimer's Disease \& Other Dementias, 17, 202-212.

Rice, M. L., Smolik, F., Perpich, D., Thompson, T., Rytting, N., \& Blossom, M. (2010). Mean length of utterance levels in 6-month intervals for children 3 to 9 years with and without language impairments. Journal of Speech, Language, and Hearing Research, 53, 333-349.

Salthouse, T. A. (1996). The processing-speed theory of adult age differences in cognition. Psychological Review, 103, 403-428.

Scott, C. (1988a). Spoken and written syntax. In M. A. Nippold (Ed.), Later language development: ages 9 through 19 (pp. 49-95). Boston, MA: Little Brown and Company. 
Scott, C. M. (1988b). A perspective on the evaluation of school children's narratives. Language, Speech, and Hearing Services in Schools, 19, 67-82.

Scott, C. M. (2009). A case for the sentence in reading comprehension. Language, speech, and Hearing Services in Schools, 40, 184-191.

Scott, C. M., \& Stokes, S. L. (1995). Measures of syntax in school-age children and adolescents. Language, Speech, and Hearing Services in Schools, 26, 309319.

Scott, C. M., \& Windsor, J. (2000). General language performance measures in spoken and written narrative and expository discourse of school-age children with language learning disabilities. Journal of Speech, Language, and Hearing Research, 43, 324-339.

Seo, H. S., \& Lee, S. H. (1999). The development of connective endings of 2-5 year old normal children. Korean Journal of Communication \& Disorders, 4, 167-185.

Shewan, C. M., \& Henderson, V. L. (1988). Analysis of spontaneous language in the older normal population. Journal of Communication Disorders, 21, 139-154.

Shin, M. S., \& Kim, H. M. (2005). Neuropsychology in neurodevelopment. Korean Journal of Child \& Adolescent Psychiatry, 16, 33-46.

Shin, Y. K., Hwang, M., \& Lim, J. A. (2018). Characteristics of expository and persuasive discourse in older adults: focusing on effective information, syntactic complexity, and mazes. Journal of Speech-Language \& Hearing
Disorders, 27, 13-27.

Sowell, E. R., Peterson, B. S., Thompson, P. M., Welcome, S. E., Henkenius, A. L., \& Toga, A. W. (2003). Mapping cortical change across the human life span. Nature Neuroscience, 6, 309-315.

Statistic Korea. (2017). Population census. http://www.kostat.go.kr.

Stine, E. L., \& Wingfield, A. (1987). Process and strategy in memory for speech among younger and older adults. Psychology and Aging, 2, 272-279.

Thordardottir, E. T., \& Weismer, S. E. (1998). Mean length of utterance and other language sample measures in early Icelandic. First Language, 18, 1-32.

Tunmer, W. E., \& Bowey, J. A. (1984). Metalinguistic awareness and reading acquisition. In W. E. Tunmer et al. (Eds.), Metalinguistic awareness in children (pp. 144-168). Heidelberg: Springer.

Yeom, J. Y. (2006). Cognitive changes in the frontal lobes across the lifespan (Master's thesis). Hallym University, Chuncheon, Korea.

Yi, B. W. (2015). Korean grammar for speech-language pathologists. Seoul, Hakjisa.

Yim, A. R., Park, E., Kim, H., \& Seo, S. (2008). Grammatical development of discourse of pre-teens. Journal of Speech and Hearing Research, 17, 17-33.

Yun, H. R. (2008). Characteristics of mean length of C-unit in word (MLCw) in story-retelling assessment. Korean Journal of Communication \& Disorders, 13, 381-396. 
Appendix 1. Criteria of data analysis

\begin{tabular}{lll}
\hline 분석 & \multicolumn{1}{c}{ 분석 요소 } & \multicolumn{1}{c}{ 분석 기준 } \\
\hline 구문 산출 & 1) 전체문장수 & 사용된 전체문장수 \\
& 2) 발화당 음절수 & 한 발화당 음절의 개수로 Jargon은 포함하지 않음 \\
& 3) 발화당 조사수 & 한 발화 내에 나타나는 조사(주격, 목적격, 부사격 등)의 수로 산정 \\
& 4) 발화당 어미수 & 한 발화 내의 선어말어미(주체높임, 시제, 공손, 상대높임, 서법, 강조)와 어말어미(종결, 비종결)수의 합 \\
& 5) 발화당 문법기능어수 & 한 발화 내의 문법적 기능어(조사, 어미)수의 합 \\
6) 평균형태소길이 & 전체 발화 표본에서 측정한 각 발화 총 형태소 수의 합을 총 발화 수로 나눔 \\
구문 길이 & 7) 평균낱말길이 & 전체 발화 표본에서 측정한 각 발화 총 낱말 수의 합을 총 발화 수로 나눔 \\
& 8) 평균어절길이 & 전체 발화 표본에서 측정한 각 발화 총 어절 수의 합을 총 발화 수로 나눔 \\
& 9) 평균구문길이 & 한 개의 형태소로 이루어진 발화는 제외하고 2개 이상의 형태소로 된 발화만을 분석하여 총 형태소의 수를 총 발화의 수로 \\
& & 나누어 평균을 구함 \\
구문 유형 & 10) 단문 비율 & 단문 수/(단문 수+복문 수) $\times 100$ \\
& 11) 복문 비율 & 복문 수/(단문 수+복문 수) $\times 100$ \\
\hline
\end{tabular}

Kim, Won, Lee, \& Yoon (2017), Lee \& Kim (2001), Kwon, Kim, Choi, Na, \& Lee (1998), Kim, Kim, Namkoong, Kim, \& Kim (2006), Koo \& Choi (2015), Kim (2014)을 참고하여 수정함. 


\section{국문초록}

초기아동기(유아기)에서 노년기까지 전생애 구문 능력 발달: 대화 자료 분석을 중심으로 윤지혜'(교수, 제1저자, 교신저자) · 정혜영(학생) · 이윤경'(교수) · 김유섭3(교수) · 최지은(학생) · 김지수3(학생)

'한림대학교 언어청각학부, ${ }^{2}$ 한림대학교 보건과학대학원 언어병리학과, ${ }^{3}$ 한림대학교 소프트웨어융합대학, ${ }^{2}$ 한림대학교 일반대학원 언어병리청각학과

배경 및 목적: 본 연구의 목적은 초기아동기에서 노년기까지의 구문 능력 발달을 살펴보고자 하였다. 방법: 연구 대상자는 총 120 명으 로 아동기, 후기아동기, 청소년, 초기성인기, 후기성인기, 노년기 각각 20 명씩으로 구성되었다. 정해진 절차에 따라 수집된 대화자료 중 50 개의 발화를 발췌하여 구문 산출 측면에서 전체문장수, 발화당 음절수, 발화당 조사수, 발화당 어미수, 발화당 기능어수, 구문 길이 측면에서 평균형태소길이, 평균낱말길이, 평균어절길이, 평균문장길이, 구문 유형 측면에서 단문 비율, 복문 비율을 측정하였다. 결과: 대부분의 구문지표는 아동기부터 청소년기까지 증가하였으며, 초기성인기에서 감소하였다가 후기성인기에서 약간 증가한 이후로는 노 년기까지 다시 감소하는 모습을 보였다. 판별분석 결과, 발화당 어미수, 발화당 기능어수, 평균형태소길이, 평균문장길이의 순으로 각 연령집단을 잘 판별해주는 지표로 나타났다. 논의 및 결론: 본 연구는 전생애적 관점에서 구문 능력의 발달 능력을 확인하기 위하여 특 정 연령대가 아닌 초기아동기부터 노년기까지 아우르는 언어발달 경향을 살펴보고 각 연령대를 구별해주는 구문 지표를 제시하였다는 점에서 의의가 있다.

핵심어: 전생애 언어발달, 구문 발달, 문장, 형태소

본 논문은 2017년도 한림 선도연구그룹지원사업(No. HRF-LGR-2017-0002)의 지원을 받아 연구되었음.

본 논문의 자료 수집과 자료 분석에 참여한 한송이, 민준상, 양예원, 오승아, 최진주, 홍원경 한림대학교 대학원생에게 감사드립니다.

\section{참고문헌}

강연욱(2006). K-MMSE (Korean-Mini Mental State Examination)의 노인 규준 연구. 한국심리학회지: 일반, 25, 1-12. 구서진, 최현주(2015). 대화와 그림설명 과제를 통한 브로카 실어증 환자의 자발화산출 특성. 재활복지, 19, 281-296. 권미선, 김향희, 최상숙, 나덕렬, 이광호(1998). 한국 성인의 자발화분석에 관한 연구: $\mathrm{CIU}$ 분석법을 중심으로. 언어청각장애연구, 3, 35-49. 권유진, 배소영(2006). 이야기 다시 말하기 과제를 통한 초등 저학년 아동의 이야기 능력. 언어청각장애연구, 11, 72-89. 김영태(1997). 한국 2-4세 아동의 발화길이에 관한 기초연구. 말-언어장애연구, 2, 5-26.

김영태(2014). 아동언어장애의 진단 및 치료(제2판). 서울: 학지사

김영태, 홍경훈, 김경희, 장혜성, 이주연(2009). 수용·표현어휘력검사(REVT). 서울: 서울장애인종합복지관.

김자성, 김정미(2011). 설명과 경험이야기에 나타난 학령기 아동 및 청소년의 구문발달 특성. 언어청각장애연구, 16, 540-558.

김정완, 김향희(2009). 알츠하이머성 치매 환자의 한국어 형태소 산출특성. 언어치료연구, 18, 75-90.

김정완, 김향희, 남궁기, 김세주, 김덕용(2006). 알츠하이머형 치매 환자의 발화특성. 언어청각장애연구, 11, 82-98.

김현아, 원새롬, 이보은, 윤지혜(2017). 노년층의 글쓰기 특성. 재활복지, 21, 193-212.

김홍근(2001). 전두엽 증후군의 임상 평가: Kims 전두엽-관리기능 신경심리검사를 중심으로. 재활심리연구, 8, 173-190.

박순혁(2015). 인지노화와 언어: 심리언어학 접근. 현대문법연구, 83, 25-39.

박윤영, 김시경(2015). 연령, 성별, 머리 크기가 대뇌 피질 두께에 미치는 효과. 생물정신의학, 22, 118-127.

박재홍, 김성환(2011). 청소년기 뇌 발달과 인지, 행동 특성. 생물치료정신의학, 17, 11-20.

배소영(1997). 한국아동의 문법형태소습득에 관한 연구: 조사 “가, 이, 는, 도, 를”. 말-언어장애연구, 2, 27-42.

서희선, 이승환(1999). 2-5세 정상 아동의 연결어미 발달. 언어청각장애연구, 4, 167-185.

신민섭, 김현미(2005). 발달 신경심리학. 소아청소년정신의학, 16,33-46. 
신윤경, 황민아, 임종아(2018). 정상 노년층의 설명하기와 설득하기 담화 산출특성. 언어치료연구, 27, 13-27.

윤혜련(2008). 이야기 평가 방법으로서의 구문복잡성(MLC-w)의 특성. 언어청각장애연구, 13,381-396.

이강현, 권도하(2002). 이야기 다시 말하기를 통한 학령기 아동의 의미 및 구문 구조 발달에 관한 연구. 언어치료연구, 11, 93-116.

이미숙, 김향희(2005). 문해능력에 따른 정상 노년층자발화의 구문적 특성. 언어청각장애연구, 10, 1-11.

이봉원(2015). 언어치료사를 위한 한국어문법. 서울: 학지사.

이영미, 김향희(2001). 대화와 그림설명과제를 통한 한국성인 발화의 비교 분석. 언어청각장애연구, 6, 1-11.

이옥분, 박상희, 손은남(2011). 20대와70대 성인화자의 자발화 정보전달력에 관한 연구. 언어치료연구, 20, 111-123.

이윤경, 최지은, 윤지혜, 김유섭, 민준상, 김지수(2017). 초기아동기에서 노년기까지 전생애 어휘 사용발달. Communication Sciences \& Disorders,

22, 717-729.

이은미, 김정미(2012). 학령전기 아동의 자발화에 나타난 언어적 비유창성 특성과 구문발달과의 관계. 언어치료연구, 21, 174-190.

이지현(2009). 학령기 아동의 구문 발달: 대화 및 이야기과제를 중심으로. 나사렛대학교 대학원 석사학위논문.

이현정, 김영태, 윤혜련(2008). 담화유형에 따른 학령기 단순언어장애 아동의 구문사용특성: 대화와 설명 담화를 중심으로. 언어청각장애연구, 13 ,

103-121.

이현정, 박창일, 박은숙, 김향희(2003). 아동의 구문발달에 따른 용언의 발달. 언어청각장애연구, 8, 20-40.

이희란(2010). 학령전 아동의 구문표현력 발달에 관한 종단연구. 언어치료연구, 19, 179-192.

이희란, 이승복(2010). 학령 전 아동의 담화결속장치 발달에 관한 종단 연구. 언어청각장애연구, 15, 298-306.

임애리, 박은숙, 김향희, 서상규(2008). 10대 초반 학생의 담화에서 나타난 구문 발달. 언어치료연구, 17, 17-33.

전영미, 김화수(2015). 정보전달능력을 중심으로 한 20대부터 50대까지의 연령대별 담화특성. 재활복지, 19, 297-320.

정윤희, 윤미선(2013). 2, 3, 4세 일반 아동의 평균발화길이. 유아특수교육연구, $13,55-73$.

진연선, 배소영(2008). 발화수집유형과 학년을 고려한 초등학생의 문법 능력. 언어치료연구, 17, 1-16.

최현주(2012). 노년층의 담화산출특성: 노화, 성별, 교육정도에 따른 차이. 말소리와음성과학, 4, 135-143.

최현주(2014). 고령자의 개인 요인 및 표현언어 능력과 정보전달 능력의 상관. 언어치료연구, 23, 51-60.

통계청(2017). 인구조사. http://www.kostat.go.kr.

하지완, 정윤희, 심현섭(2009). 알츠하이머 치매 및 치매의심 집단과 정상 노인의 발화 비교분석을 통한 삽입어(filler)의 기능 연구. 언어청각장애연구,

14, 514-530.

황순택, 김지혜, 박광배, 최진영, 홍상황(2012). 한국판 웩슬러 성인용 지능검사4판(K-WAIS-IV). 서울: 학지사. 